\title{
Nano-Adsorbents for Cobalt Removal from Wastewater: A Bibliometric Analysis of Research Articles Indexed in the Scopus Database
}

\author{
Charikleia Prochaska*(D) and George Gallios
}

Laboratory of Chemical and Environmental Technology, School of Chemistry, Faculty of Science, Aristotle University of Thessaloniki, 54124 Thessaloniki, Greece; gallios@chem.auth.gr

* Correspondence: prohaska@chem.auth.gr

Citation: Prochaska, C.; Gallios, G. Nano-Adsorbents for Cobalt Removal from Wastewater: A Bibliometric Analysis of Research Articles Indexed in the Scopus Database. Processes 2021, 9, 1177. https://doi.org/ $10.3390 /$ pr9071177

Academic Editors: Andrea Melchior and Sebastián Sánchez Villasclaras

Received: 1 June 2021

Accepted: 4 July 2021

Published: 6 July 2021

Publisher's Note: MDPI stays neutral with regard to jurisdictional claims in published maps and institutional affiliations.

Copyright: (c) 2021 by the authors. Licensee MDPI, Basel, Switzerland. This article is an open access article distributed under the terms and conditions of the Creative Commons Attribution (CC BY) license (https:/ / creativecommons.org/licenses/by/ $4.0 /)$.

\begin{abstract}
In this study, a combined technique of bibliometric and social network analysis was applied on research articles, related to the application of nano-adsorbents for cobalt removal from wastewater, published in Scopus database up to 2020. The results revealed that the first relative research article appeared in the Scopus database in the year 2002. The total output of research articles reached 214 in the year 2020. Published research articles of the years 2014-2020, added up to $83.6 \%$ of total articles. King Saud University of Saudi Arabia, Chinese Academy of Science, and LUT University of Finland were found to serve as the gatekeepers who control information flows in the network of the most prolific institutions, while cooperation between China, Saudi Arabia, and United States was also identified. On average, the most prolific authors cooperated with five others, while the top 10 cited publications appeared to represent a sparse and weakly interconnected network of co-authors. Graphene oxide was the most prominent nano-adsorbent among the top 10 cited publications, and their respective co-citations network visualization helped in capturing the value of certain citations to the evolution of the research on the topic, putting thus scientific work impact assessment to a different perspective.
\end{abstract}

Keywords: bibliometrics; centrality; social network analysis Gephi; VOSviewer; scopus database; cobalt adsorption; nano-adsorbents; graphene oxide

\section{Introduction}

Cobalt (Co) was discovered in 1735 due to the studies of the Swedish chemist Georg Brandt (1694-1768), who served at that time as the director of the chemistry laboratory at the Bureau of Mines in Stockholm, Sweden. The blue material called "smalt" had been used from the Antiquity to add a deep blue color to objects of glass and porcelain. It had previously been thought to contain bismuth or copper and even iron and arsenic. At the time of Brand's discovery the word "cobalt" referred to the ore from which the "smalt" was prepared, rather than to the metal itself [1]. The word cobalt originated from the German word "Kobold" which means a "demon". The German miners used the term in the 16th century to describe the "unknown", at that time, substance in copper-arsenic-silver mineral ores that caused toxic fumes and prevented them from applying the traditional extraction processes of copper and/or silver. The toxic fumes were later on attributed to arsenic species evaporated during roasting of the ores [2], and it was from these ores that Brandt prepared and identified cobalt metal, which he called "cobalt regulus", classifying it as a semi-metal, distinguishing it from true metals of that time on the basis of malleability [1]. Cobalt is classified as the first and lightest element among the group 9 of transition metals of the periodic chart of elements, having unique physical properties, including heat resistance, strength, and magnetic properties [3].

Due to these physical properties, cobalt applications have evolved ever since its discovery [4]. Thus, cobalt has been used systematically from the early 1900s in paint, 
pigment, electroplating industries, as catalyst in petrochemical and plastic industries [5], and in alloys with iron and other metals [6]. This last application dominated in the 1990s, where cobalt was used in the production of very hard superalloys, predominantly nickelbased [7], which are highly resistant against temperature, corrosion, and oxidation [8], and are mainly used in aircraft jet engines [9]. Currently, it is the rechargeable Li-ion battery industry that dominates the global cobalt market, being responsible for $58 \%$ of cobalt use [10].

According to recent estimations, the global cobalt consumption is expected to reach 220,000 tons in 2025 and 390,000 tons in 2030, due to the rapid growing demand for batteries required also for electric vehicles. That means that the cobalt demand is expected to increase by $183 \%$ in 2030 [11]. Currently the bulk of global cobalt production emanates as a by-product of extraction of commodities such as copper $(\sim 55 \%)$, nickel $(\sim 35 \%)$, and arsenic [12]. Almost half of the global cobalt supply is produced annually from a primary source, a weathered stratiform sediment-hosted $\mathrm{Cu}$-Co ore, located in the Democratic Republic of Congo (DRC) [13], while the production of refined cobalt metal is currently dominated by China $(\sim 67 \%)$, followed by Finland $(\sim 11 \%)$ and Canada $(\sim 5 \%)$ [2]. Due to the cobalt's economic importance, its major uses in the industry and its concentration in only a few places worldwide, cobalt has been identified as "critical" raw material by the European Commission [14] and the U.S.A. Department of Energy [15], motivating the development of technologies for cobalt recovery and reuse [11,16].

While dissolved cobalt occurs naturally in surface and ground water in concentrations that do not exceed $0.8 \mu \mathrm{g} / \mathrm{L}$ [17], elevated cobalt concentrations of $0.9 \mathrm{mg} / \mathrm{L}$ have been detected in water resources, affected by run-offs from mines and from industrial effluents [18]. Average grey and blackwater cobalt concentrations of $1.36 \mu \mathrm{g} / \mathrm{L}$ and $0.86 \mu \mathrm{g} / \mathrm{L}$, respectively, have been detected in ordinary Swedish households [19], due to the use of shampoos, conditioners, and detergents [20]. Cobalt concentrations in the range of 60 to $6000 \mathrm{mg} / \mathrm{L}$ can be found in industrial wastewater [21]. Although no permissible limit has been established for cobalt in drinking water by World Health Organization (WHO) and cobalt is generally considered as one of the heavy metals that cause no major environmental concerns, and it is also a bio-essential element, as part of vitamin B12 [22], the increase of cobalt discharges into water bodies led, in 1986, the New York State Department of Environmental Conservation to impose a water quality standard for surface and ground water of $5 \mu \mathrm{g} / \mathrm{L}$ cobalt [17]. In 2019, the Wisconsin Department of Health Services recommended that the ground water limit for cobalt has to be set at $4 \mu \mathrm{g} / \mathrm{L}$ [23]. Meanwhile, several countries worldwide have set national permissible limit of cobalt in the irrigation water to $0.05 \mathrm{mg} / \mathrm{L}$ [24]. Recent studies have shown that cobalt at high concentrations ( $\geq 5 \mathrm{mg} / \mathrm{L})$ [25] can pose health risk, with symptoms related to asthma, damage of the liver thyroid, and the heart. Cobalt has been reported to cause also genetic mutations in living organisms [26-28], while in other studies cobalt has been reported as possible carcinogen [29].

The need to protect human health and the environment, along with the increasing water demand and the urge for both water reuse and cobalt recovery and reuse from aqueous solutions, shifted research interest to the effective removal of Co from the wastewater [28]. Cobalt occurs in two oxidation states, $\mathrm{Co}^{2+}$ and $\mathrm{Co}^{3+}$, in aquatic environment. However, with the exception of certain complexes, $\mathrm{Co}^{3+}$ is thermodynamically unstable under the redox and $\mathrm{pH}$ conditions that commonly occur in natural waters [17]. ${ }^{60} \mathrm{Co}$ hazardous radioactive isotope, found in radioactive wastewater effluents, also always exists in the ionic form of $\mathrm{Co}^{2+}$ in water environments [21]. Advanced wastewater-treatment methods, such as ion exchange, precipitation, membrane separation, and electrolysis, have been used for cobalt removal from wastewater [30,31]. However, most of these methods are costly and require high levels of expertise. Therefore, interest has shifted to the adsorption technology, which is simple, economic, and versatile. $\mathrm{Co}(\mathrm{II})$ ions $\left(\mathrm{Co}^{2+}\right)$ have been considered a good model pollutant for adsorption studies over the last decade [30]. Nanomaterials, substances with a particle size of $1 \mathrm{~nm}$ to $100 \mathrm{~nm}$ in at least one dimension [32], for Co(II) adsorption 
from wastewater, have been developed, over the last ten years, aiming to overcome conventional adsorbents limitations [33]. Most of the nano-adsorbents investigated for $\mathrm{Co}$ (II) removal from wastewater fall into the categories of metal [34] and metal oxide nanomaterials [32], carbon-based nanomaterials [35,36] and polymer-based nanomaterials $[37,38]$. Even though these nanomaterials have shown high adsorption capacity values, further research and development is needed, up to the stage of their commercialization and their application to full scale wastewater treatment, as they exhibit certain limitations [28].

Apart from the conventional review studies of the progress made by scholars, bibliometric studies can also be beneficial for deepening the research and improving the understanding of research patterns and co-operations on the topic of nano-adsorbents for $\mathrm{Co}$ (II) removal from wastewater. Bibliometric methods, whose origins can be traced back to the 1920s [39], are now well established [40] and used as a comprehensive technique, related to mathematical and statistical methods to figure out publication distribution, variation, and relationships quantitatively based on public databases, such as Scopus [41]. Applying the tools of bibliometric analysis, an overview of the research landscape can be revealed and guidance on future research can be offered, in a much different way than research review articles do. Jieng et al. [42], in their recent bibliometric research published in 2018 on the role of nanomaterials in wastewater treatment over the last decade, observed strong cooperation on research publications between China and USA and identified graphene, magnetic nanoparticle, and nanocomposites as research hotspots.

As the bibliometric analysis articles focusing on the role of nanomaterials in wastewater treatment are limited $[41,43,44]$, and none so far have been published focusing only to nano-adsorbents for $\mathrm{Co}$ (II) removal from wastewater, this study aims to help reveal hidden research trends, gain novel insights on scientific developments in this research area, and improve bibliometric reliability. The study is based on research articles indexed in Scopus database, the largest curated abstract and citation database of research literature in the world today [45], with combined techniques of bibliometric and social network analysis.

\section{Methods}

\subsection{Data Collection}

The publications considered for this study were obtained from the Elsevier's Scopus database through the searching process presented in Table 1. Scopus was selected on the basis that it possesses a larger coverage of peer-reviewed publications in all fields, provides reliable bibliographic data [46], and offers $\sim 5 \%$ more coverage than Web of Science in the field of Natural Science and Engineering [47], whereas Google Scholar offers results of inconsistent bibliometric accuracy, as it works as a search engine of the whole internet which narrows the results to "scholarly" ones, based on machine-automated criteria [48]. Applying the appropriate syntax of Scopus database, the search approach was created on the basis that the acquired research publications were to be retrieved from a dataset that would be as broad, complete, and relevant as possible. In that sense, the search included all years, all subject areas, and used title-abstract and keywords for retrieving the appropriate literature. Four sets of search terms were identified as the most relevant: adsorption, cobalt, wastewater, and nanomaterials. The four sets were combined using AND. Within the sets, related terms were combined using OR, exact phrases were put in double quotations marks and words with common roots were truncated using an asterisk, e.g., by using nano* Scopus searched for nanomaterials, nanoadsorbents, nano-adsorbent, nanosorbents, nanocellulose, and so on. The results were limited to include only publications in English and journal articles; their titles and abstracts were then thoroughly reviewed to collect the relevant publications. The search was conducted on 16 April 2021. Note that along with the applied query string and the exact number of articles retrieved (Supplementary material, S1), the exact date that the search was conducted on Scopus database needs also to be stated. The reason is that any application of the exact same query string on Scopus database at any subsequent time (e.g., later than 16 April 2021) will yield, inevitably, a 
larger number of articles (than the 6417 , stated here) as the database does not provide the option to limit search results by an exact date (e.g., by 16 April 2021).

Table 1. Search approach on Scopus database.

\begin{tabular}{|c|c|}
\hline Search Parameter & Scopus Search Syntax \\
\hline Category & Title-Abstract-Keywords (TITLE-ABS-KEY) \\
\hline Subject area & ALL \\
\hline Time period & ALL Years \\
\hline Sets of search terms & 4 \\
\hline Combination of Sets & Combined using AND \\
\hline Related terms & Related using OR \\
\hline Exact phrases & Double quotations marks " " \\
\hline Words with common roots & Truncated using the asterisk * symbol \\
\hline Filters & $\begin{array}{c}\text { Language: English LIMIT-TO } \\
\text { (LANGUAGE,"English") } \\
\text { Document type: Article LIMIT-TO (DOCTYPE, “ar") } \\
\text { Source type: Journal LIMIT-TO (SRCTYPE,"j") }\end{array}$ \\
\hline Search Date & $16-4-2021$ \\
\hline Exact Query String & 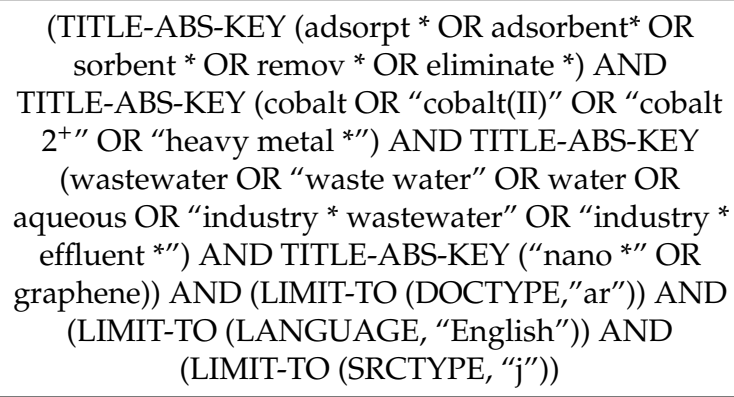 \\
\hline Total documents (initial search) & 6417 (Supplementary Material, file S1) \\
\hline
\end{tabular}

\subsection{Data Bibliometric Analysis}

The growth of research articles on Scopus database was analyzed using the Annual Growth Rate (AGR) and two parameters that are related to each other: the Relative Growth Rate (RGR) and the Doubling time (Dt), estimated on a year-by-year basis [49].

The AGR is estimated, using the formula [50]

$$
\text { AGR }=\frac{\text { Certain year No of articles }- \text { Previous year No of articles }}{\text { Previous year No of articles }} \times 100
$$

The RGR represents growth in research output and is calculated using the following formula [50]:

$$
\mathrm{RGR}=(\ln \mathrm{N} 2-\ln \mathrm{N} 1)
$$

where N2 and N1 are, respectively, the cumulative number of publications in the year of interest and in the previous year. Dt is directly related to RGR and reflects the time required for publications to become double of the existing amount. If the number of articles doubles during a given period, then the difference between the natural logarithms must be 0.693 , the natural logarithm of number 2. Thus, Dt is calculated, using the following formula [50]:

$$
\mathrm{Dt}=0.693 / \mathrm{RGR}
$$

The collaboration index (CI) of an author was calculated as the total number of authors of co-authored research articles divided by the total number of multi-authored articles [51].

For journals' impact factor and for their respective quartile ranking, data of the year 2020 were used, as found in the Journals' Citation Report by Clarivate Analytics [52]. 
The Hirsch index (h-ndex) [53], introduced to characterize the scientific output of a researcher, was applied as a useful index to quantify the impact of the publications of the most prolific authors as well as the most profic journals and institutions. It was calculated as the number of papers with citations number $\geq h$.

\subsection{Data Visualization}

Two open-source and freely available softwares were used for data visualizations.

VOSviewer version 1.6.16 was downloaded from https:/ / www.vosviewer.com (Accessed on 16 April 2021). The software that was firstly introduced in 2009 [54], is completely focused on the visualization of bibliometric networks, it takes Scopus data export files in csv (comma separated values) text format as input, and demands no preparation of the data acquired from Scopus. It has an easy-to-follow wizard for authors' keywords co-occurrence visualization; thus, in this study, VOSviewer was used exclusively for the network visualization of the top 10 co-occurring authors' keywords.

Gephi, version 0.9.2, downloaded from https:/ / gephi.org (Accessed on 16 April 2021), was applied to display all the other networks of this study. Gephi software was created in 2009 for social network visualization and common statistics/metrics for social network analysis [55]. With Gephi the visualizations can be customized according to the user's needs. When Gephi was used, Scopus export csv files were edited in excel, according to the needs of each particular visualization, the edited excel files were then saved in csv format and the corresponding network was extracted in GEXF file format (Graph Exchange XML Format), the default Gephi graph file format, before loaded to Gephi software. This last step was made by using the online Table2net application, available at https:/ / medialab.github.io/table2net/ (Accessed on 16 April 2021). The Table2net online tool, developed by one of Gephi's creators, allows the extraction of a Gephi file format (GEFX) from a csv file, by adjusting online a simple series of settings.

\section{Results and Discussion}

\subsection{Annual Growth of Research Articles}

The bibliometric analysis, regarding the annual production of research articles, concerning the use of nanomaterials as adsorbents for Co(II) removal from wastewater, is presented in Table 2. The search produced 6417 documents. Their titles and abstracts were then thoroughly reviewed, manually. This was the most time-consuming part of the process, but it had to done carefully so as all the relevant research articles to be retrieved from the initial broad dataset of the 6147 publications, e.g., the initial dataset contained articles that referred to heavy metals' nano-adsorption removal from wastewater and only through reading of both their title and abstract it was possible to identify if cobalt was included in the heavy metals. Furthermore, in order to provide another example of the necessity of the applied screening process, there were articles included in the initial dataset that used adsorbents to remove cobalt from wastewater and only through reading of both their title and abstract it was possible to identify if nano-adsorbents were used. The development of semiautomated or fully automated, hopefully in the future, title-abstract screeners are supposed to facilitate this process; however, as there are still limitations to the applicability of such semiautomated title-abstract screening tools [56], the manual screening approach remains inevitable. The approach resulted in 229 relevant publications. Fifteen research articles were retrieved for the year 2021, but as the search was conducted in April 2021, the total number of research articles indexed on Scopus for the year 2021 was not complete, thus publications indexed later than 2020 were not included in this analysis; however, the total number of citations that the publications received was assessed up to the date that the search results were exported from Scopus database. The first relative research article, appeared on Scopus database, in the year 2002. The total output of research articles expanded from 1, in the year 2002, to 214 research articles in the year 2020 (Supplementary material, file S2). Published research articles of the years 2014-2020, added up to $83.6 \%$ of total articles. The highest annual growth rate value of $280 \%$ was produced in the year 2014 . 
Table 2. Annual production and growth of research articles.

\begin{tabular}{ccccccc}
\hline Year & $\begin{array}{c}\text { No } \\
\text { of } \\
\text { Research } \\
\text { Articles }\end{array}$ & $\begin{array}{c}\text { Percentage } \\
\text { of } \\
\text { Research } \\
\text { Articles } \\
\mathbf{( \% )}\end{array}$ & $\begin{array}{c}\text { Cumulative } \\
\text { Sum of } \\
\text { Research } \\
\text { Articles }\end{array}$ & $\begin{array}{c}\text { Annual } \\
\text { Growth } \\
\text { Rate } \\
\text { (AGR) }\end{array}$ & $\begin{array}{c}\text { Relative } \\
\text { Growth } \\
\text { Rate } \\
\text { (RGR) }\end{array}$ & $\begin{array}{c}\text { Doubling } \\
\text { Time } \\
\text { (D) }\end{array}$ \\
\hline 2002 & 1 & 0.5 & 1 & - & - & - \\
2003 & 1 & 0.5 & 2 & 0.0 & 0.7 & 0.9 \\
2004 & 1 & 0.5 & 3 & 0.0 & 0.4 & 1.6 \\
2005 & 1 & 0.5 & 4 & 0.0 & 0.3 & 2.2 \\
2006 & 3 & 1.4 & 7 & 200.0 & 0.6 & 1.1 \\
2007 & 1 & 0.5 & 8 & -66.7 & 0.1 & 6.4 \\
2008 & 2 & 0.9 & 10 & 100.0 & 0.2 & 3.2 \\
2009 & 3 & 1.4 & 13 & 50.0 & 0.3 & 2.1 \\
2010 & 2 & 0.9 & 15 & -33.3 & 0.1 & 6.4 \\
2011 & 9 & 4.2 & 24 & 350.0 & 0.5 & 1.3 \\
2012 & 6 & 2.8 & 30 & -33.3 & 0.2 & 3.2 \\
2013 & 5 & 2.3 & 35 & -16.7 & 0.2 & 3.2 \\
2014 & 19 & 8.9 & 54 & 280.0 & 0.4 & 1.6 \\
2015 & 32 & 15.0 & 86 & 68.4 & 0.5 & 1.3 \\
2016 & 36 & 16.8 & 122 & 12.5 & 0.3 & 2.1 \\
2017 & 27 & 12.6 & 149 & -25.0 & 0.2 & 3.2 \\
2018 & 21 & 9.8 & 170 & -22.2 & 0.1 & 6.4 \\
2019 & 26 & 12.1 & 196 & 23.8 & 0.1 & 6.4 \\
2020 & 18 & 8.4 & 214 & -30.8 & 0.1 & 6.4 \\
Total/ & 214 & 100.0 & 1143 & 45.1 & 0.3 & 3.1 \\
Average & & & & & & \\
\hline
\end{tabular}

As noted in several bibliometric research studies, the production of scientific publications is, in general, characterized by three successive stages, even though, each scientific field, undergoes its own growth process [57]. The stages, initially identified by Price [58] in 1956, are the precursors' stage (initial publications), the exponential growth stage (become a major focus of research), and the linear growth stage (growth slows down). It is indicated, by the RGR and the corresponding DT values of Table 2, that the annual growth of the research articles of this study was neither fully exponential nor linear. The RGR values showed a decreasing trend with fluctuations. The corresponding DT values denoted an increasing trend, with several ups and downs, while the value of DT remained constant to 6.4 for the years 2018, 2019, and 2020, meaning that 6.4 years are needed so as each of these years publications to be doubled.

Figure 1 represents the annual growth of research articles, along with the cumulative sum of the articles and its exponential trendline fit. Even though the R-squared value of the exponential function is 0.987 , the graphical representation of the model, along with the calculated value of the square root of the variance of the residuals (RMSE) [57], which is 20.38, reflects the poor ability of the exponential growth model to accurately predict the data in recent years and especially as regards the data points of the years 2019 and 2020, where the model overfits the actual data. This drop in the publications' output must be considered in respect to the COVID-19 outbreak, as during this period many fields of science, not directly related to the pandemic, have lagged behind [59]. However, this assumption remains to be validated in the future, by comparing the publications' production during the pandemic with the growth of publications in the forthcoming years. 


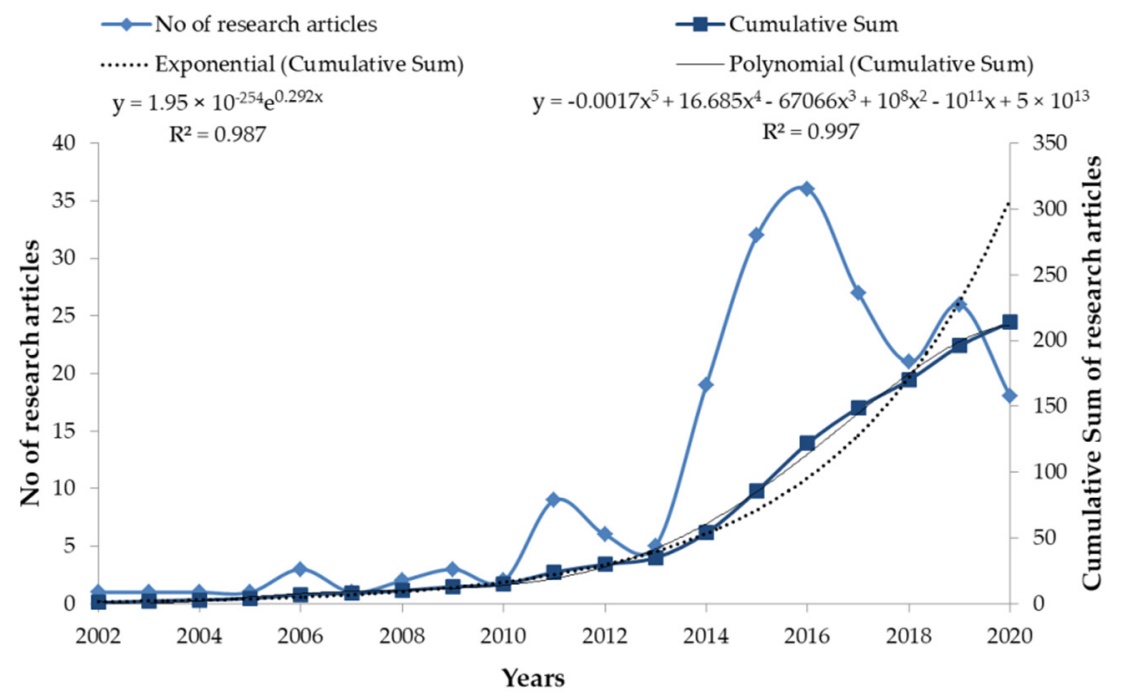

Figure 1. Annual production of research articles.

Despite the fact that growth of the research papers related to nano-adsorbents for $\mathrm{Co}$ (II) removal from wastewater is not in its exponential phase, as a fifth-degree polynomial model better fits the datapoints, as seen in Figure 1, the trend is definitely increasing and that can lead to greater focus on the subject in the forthcoming years.

\subsection{Top 10 Publication Sources}

The 214 publications on Scopus database were processed in order to identify the most prolific journals that scientists have turned to in order to publish work related to the application of nano-adsorbents for $\mathrm{Co}$ (II) removal from wastewater. The top 10 journals retrieved on Scopus database, as regards the amount of relative publications, are presented in Table 3. The retrieved journals are presented along with the corresponding number of total citations, received by the publications, the value of Hirsch index (h-index), the journals' 2020 impact factor, and their quintile ranking.

Table 3. Main journals of publications.

\begin{tabular}{|c|c|c|c|c|c|c|c|}
\hline Rank & Journal Title & $\begin{array}{c}\text { No of } \\
\text { Research } \\
\text { Articles }\end{array}$ & $\begin{array}{c}\text { Total } \\
\text { Citations }\end{array}$ & $\begin{array}{c}\text { h- } \\
\text { Index }\end{array}$ & $\begin{array}{l}\text { Start } \\
\text { Year }\end{array}$ & $\begin{array}{c}2020 \\
\text { Journal } \\
\text { Impact Factor }\end{array}$ & Quartile \\
\hline 1 & Chemical Engineering Journal & 13 & 1197 & 13 & 2011 & 10.652 & Q1 \\
\hline 2 & Desalination and Water Treatment & 12 & 46 & 4 & 2015 & 0.854 & $\mathrm{Q} 4$ \\
\hline 3 & Journal of Hazardous Materials & 11 & 1382 & 10 & 2009 & 9.038 & Q1 \\
\hline 4 & $\begin{array}{c}\text { Journal of Radioanalytical and } \\
\text { Nuclear Chemistry }\end{array}$ & 10 & 94 & 6 & 2006 & 1.137 & Q3 \\
\hline 5 & RSC Advances & 8 & 193 & 8 & 2013 & 3.119 & Q2 \\
\hline 6 & Microchimica Acta & 6 & 191 & 6 & 2016 & 6.232 & Q1 \\
\hline 7 & $\begin{array}{l}\text { Journal of Colloid and Interface } \\
\text { Science }\end{array}$ & 5 & 288 & 5 & 2004 & 7.489 & Q1 \\
\hline 8 & Journal of Molecular Liquids & 5 & 177 & 5 & 2015 & 5.065 & Q1 \\
\hline 9 & $\begin{array}{l}\text { Journal of Industrial and } \\
\text { Engineering Chemistry }\end{array}$ & 4 & 170 & 4 & 2014 & 5.278 & Q1 \\
\hline 10 & Carbohydrate Polymers & 3 & 208 & 3 & 2014 & 7.182 & Q1 \\
\hline $\begin{array}{l}\text { Total/ } \\
\text { Average }\end{array}$ & & 77 & 3901 & 6 & 2012 & 5.6046 & Q2 \\
\hline
\end{tabular}

The top 10 journals received in total 77 research articles and 3901 citations (including citations made up to 15 April 2021). These values correspond to $36 \%$ of total articles and to 
$44 \%$ of total citations. The corresponding h-index was in the range of 4 to 13 . "Chemical Engineering Journal" tops the list with 13 publications.

As observed from data of Table 3, the quality of the journal strongly affects the total number of citations received, as there were journals of similar number of published articles or journals that published earlier and yet depicted a smaller number of citations, compared to the ones with higher impact factors. The majority of the top 10 journals (seven out of 10) were of high quality, falling to the first quartile (Q1), meaning that they were ranked among top $25 \%$ journals in the same subject area.

Each of the top 10 journals of Table 3 were categorized in Scopus database to either a single or multiple subject areas. The subject areas can provide a better understanding of the focus of the research, compared to what is revealed by assessing only each journal's title. Figure 2 shows the number of articles published in each journal along with the subject area/areas that each journal belongs to. Seventy-three percent of the 77 publications fell into four subject categories: "Environmental Science", "Chemistry", "Chemical Engineering", and "Engineering". In that respect, environmental protection can be considered as the driving force for research related to Co(II) removal from wastewater. Moreover, research on the removal of Co(II) from radioactive wastewater was limited, as "Energy" and "Medicine" subject areas accounted each only $5.40 \%$ of the publications. Furthermore, "Chemistry" was a major subject of research, accounting for $24.50 \%$ of publications. Furthermore, even though nano-adsorbents are nanomaterials, and thus "Material Science" subject could be expected to serve as a major contributing category, it accumulated only $7.10 \%$ of the publications.

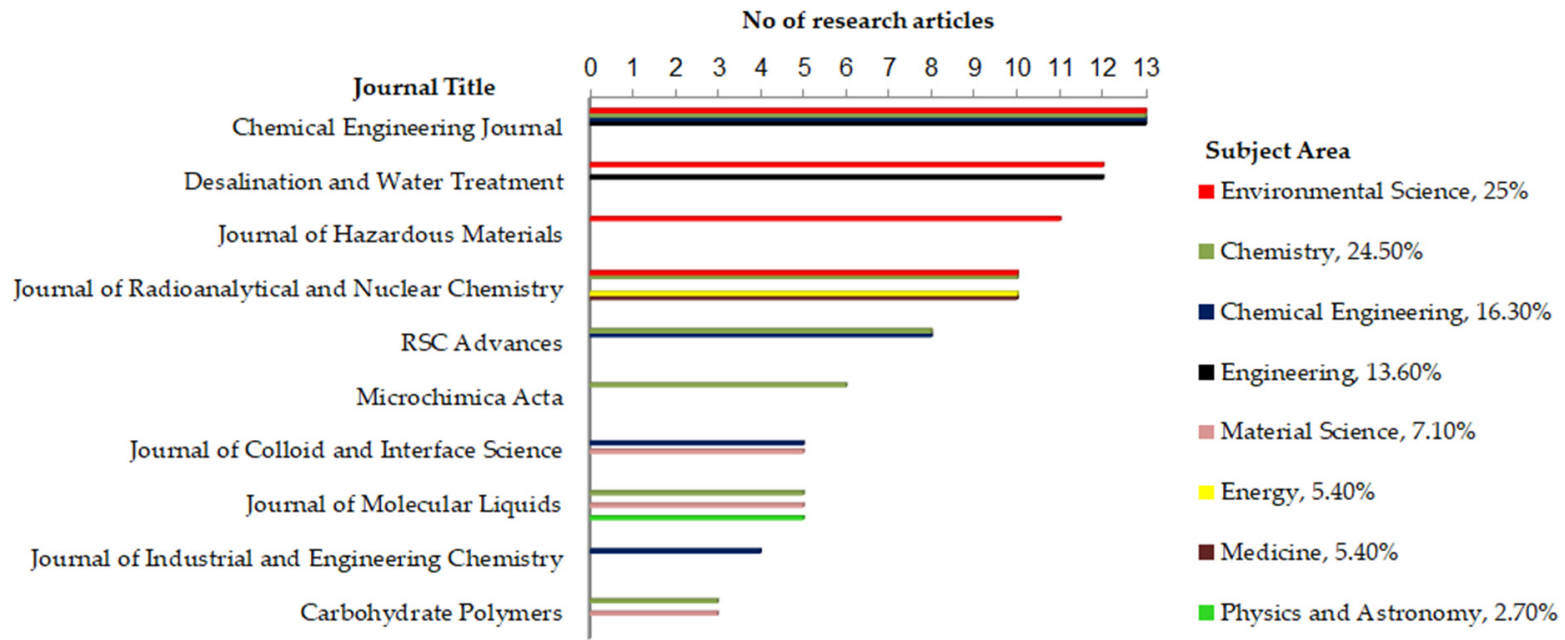

Figure 2. Ranking of top 10 journals: No of articles and relevant subject areas, with percentages of articles within each subject area.

\subsection{Top 10 Institutions}

After identifying the top 10 publication sources, the corpus of the 214 publications was processed so as to identify the major institutions with the higher amount or research published, related to the application of nano-adsorbents for Co(II) removal from wastewater. Scopus does not consider different departments of the same institution as separate units in evaluating institutions' outputs; this approach was also followed here and Scopus' data were processed in Excel to avoid any duplicate entries, e.g., authors with two or more affiliations that add up the same output to multiple institutions. The most productive institutions are presented in Table 4, along with their country of origin and the values of the following scientometric indicators: the total No of research articles, the total No of citations, h-index, and start year of research publications, for the data corresponding to each of these institutions. 
Table 4. Top 10 productive Institutions.

\begin{tabular}{|c|c|c|c|c|c|c|}
\hline Rank & Institution & Country & $\begin{array}{c}\text { No of } \\
\text { Research } \\
\text { Articles }\end{array}$ & $\begin{array}{c}\text { Total } \\
\text { Citations }\end{array}$ & $\begin{array}{c}\text { h- } \\
\text { Index }\end{array}$ & $\begin{array}{l}\text { Start } \\
\text { Year }\end{array}$ \\
\hline 1 & Chinese Academy of Sciences & China & 17 & 2123 & 12 & 2006 \\
\hline 2 & $\begin{array}{c}\text { Atomic Energy Authority of } \\
\text { Egypt }\end{array}$ & Egypt & 11 & 134 & 7 & 2015 \\
\hline 3 & University of Tehran & Iran & 9 & 160 & 6 & 2015 \\
\hline 4 & King Saud University & $\begin{array}{l}\text { Saudi } \\
\text { Arabia }\end{array}$ & 7 & 335 & 6 & 2014 \\
\hline 5 & Ministry of Education China & China & 6 & 100 & 5 & 2014 \\
\hline 6 & $\begin{array}{c}\text { Amirkabir University of } \\
\text { Technology }\end{array}$ & Iran & 6 & 92 & 4 & 2015 \\
\hline 7 & LUT University & Finland & 5 & 356 & 5 & 2013 \\
\hline 8 & Tsinghua University & China & 5 & 233 & 5 & 2016 \\
\hline 9 & Erciyes Üniversitesi & Turkey & 4 & 157 & 3 & 2016 \\
\hline 10 & $\begin{array}{l}\text { Al-Imam Muhammad Ibn } \\
\text { Saud Islamic University }\end{array}$ & $\begin{array}{l}\text { Saudi } \\
\text { Arabia }\end{array}$ & 4 & 17 & 3 & 2015 \\
\hline $\begin{array}{l}\text { Total/ } \\
\text { Average }\end{array}$ & & & 74 & 3710 & 6 & 2014 \\
\hline
\end{tabular}

Chinese Academy of Sciences tops the list in respect to both the total No of published research articles, with 17 papers and the total No of citations, with 2123 citations (as evaluated on the 15 April 2021). The institution also demonstrated the highest value of h-index (h-index of 12). Note that two more Chinese institutions rank 5 and 8 in the list of 10. China's increasing control over cobalt resources in the DRC as well as its domination on the production of refined cobalt metal is clearly reflected in the results of this institutions' research activity ranking, in terms of the production of publications and citations' output. The fact that Finland follows China in the production of refined cobalt metal explains why LUT University of Finland, ranked 7th place, was the only Western institution that added up to this top-10 institutions' ranking.

Countries' Based Network Analysis of the Top 10 Institutions

In order to identify international cooperation patterns of the most productive institutions, Table 2's institutions' publications were evaluated according to the authors' country affiliations and the institution network of countries was visualized by Gephi software (Figure 3). For visualization, Gephi's default ForceAtlas layout algorithm was used. ForceAtlas is a force-directed layout that simulates a physical system in which the individual units of analysis (nodes in Gephi's network terminology) are little balls electrically charged and the links (edges in Gephi's network terminology) are springs that connect them to other type of nodes. The algorithm applies two opposite forces to the nodes, one attractive (proportional to the weight of the link between two nodes) and the other repulsive, until the system comes to a state of mechanical equilibrium [55]. The layout demands no specialized knowledge on graph theory and results in a visually pleasant configuration, helpful for the interpretation of the data. Thus, by applying the algorithm, institutions and countries that were related to each other were grouped together, while those institutions that did not cooperate with the same countries were placed in distance. By applying Gephi's modularity metrics to the dataset [60], six clusters were identified and colored accordingly. The more active the institution or the country was, in terms of collaboration, the bigger was its circular representation (node size in Gephi's network terminology). Furthermore, nodes' labels were font-sized in respect to the nodes' size. For scaling the nodes, Gephi's Betweeness Centrality (BC) statistics was applied. BC shows the institution's capacity to connect with other countries within the network [61]. Thus, institutions with high betweenness rates can be considered to serve as gatekeepers who control information flows in the network [62]. Through the network visualization it can be 
identified that King Saud University $(B C=137)$, Chinese Academy of Science $(B C=113)$, and LUT University of Finland $(B C=107)$ were in good position within the network.

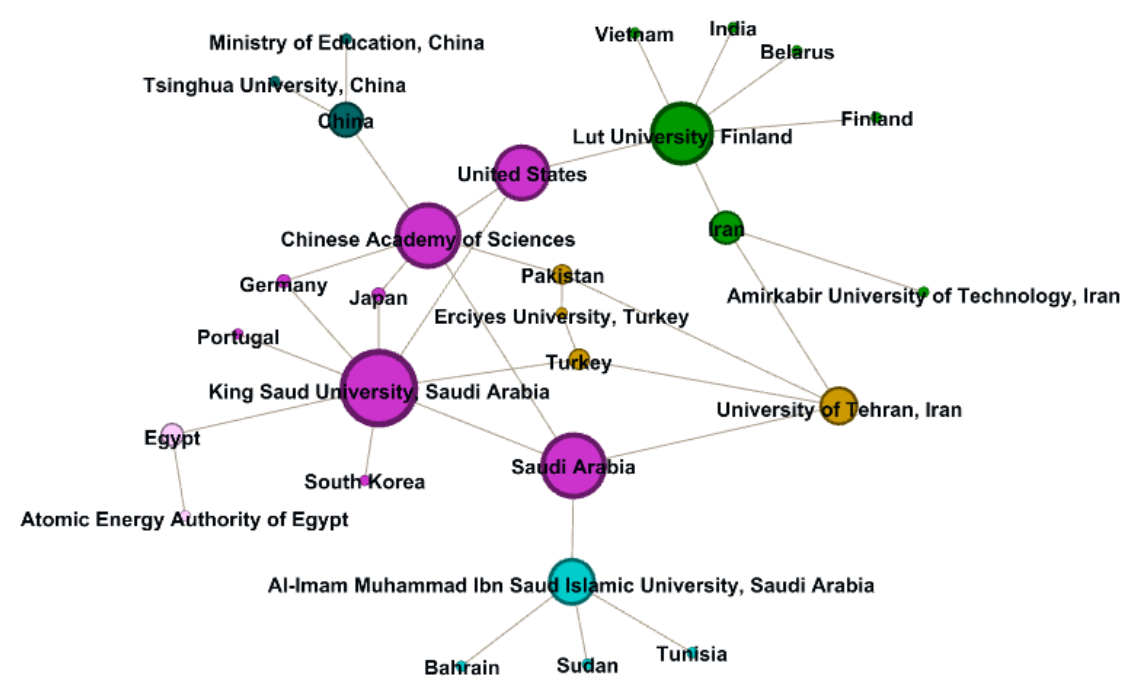

Figure 3. Countries' co-authorship network of the top 10 institutions.

In respect to the countries' visualization and corresponding statistics, the presence of United States is noteworthy, even though none of the most productive institutions originated in this county, still United States followed Saudi Arabia in BC (92 and 112, respectively) and had equal value of closeness centrality with Saudi Arabia (0.4), meaning that those two countries had the shortest distance to the other institutions of the network. The high closeness centrality represents the effectiveness and key role of those two countries in the distribution of information in the network, as closeness centrality was developed in order to measure the extent of influence of certain nodes over the entire network. It is calculated as the average of the shortest path length from the node to every other node in the network [63].

Interestingly, some other countries, such as Germany, Japan, and Pakistan, have found their way into being affiliated by more than one institution. Iran was followed by China in BC (47 compared to China's 51) and clustered together with LUT and Amirkabir Universities, while China was clustered along with Tsinghua University and the Chinese Ministry of Education and not with the Chinese Academy of Science, which was identified as the main contributor of research papers in Table 4's data. The case of the Chinese Academy of Science is interesting because the visualization in Figure 4 showed that this institution (which is a large research organization comprising over 100 institutes [64]) not only had many domestic authorships, but that its role could be considered as intermediary between the two other Chinese institutions (with exclusive domestic co-authorship) and foreign partners.

\subsection{Top 10 Authors}

Table 5 presents a ranking of the most prolific authors, having the highest amount of published research, related to the application of nano-adsorbents for $\mathrm{Co}$ (II) removal from wastewater, in the corpus of 214 publications. The ranking was made based on the total number of research papers appeared on Scopus' dataset and among authors with the same amount of publications, the one with the higher number of total citations was placed ahead. As presented in Table 5, the 10 most prolific authors published in total 42 research articles (20\% of total publications), the publications were made between 2011-2016, the authors had an h-index in the range of 3 to 7 , and a collaboration index (CI) in the range of 3-7. The 10 most prolific authors presented in Table 5 demonstrated an average CI value of 5, suggesting that the research publication was, in average, produced by five authors in the 
field. Wang X. from Chinese Academy of Sciences topped the list, with seven publications, 1839 citations, an h-index of 7, and a CI of 6.

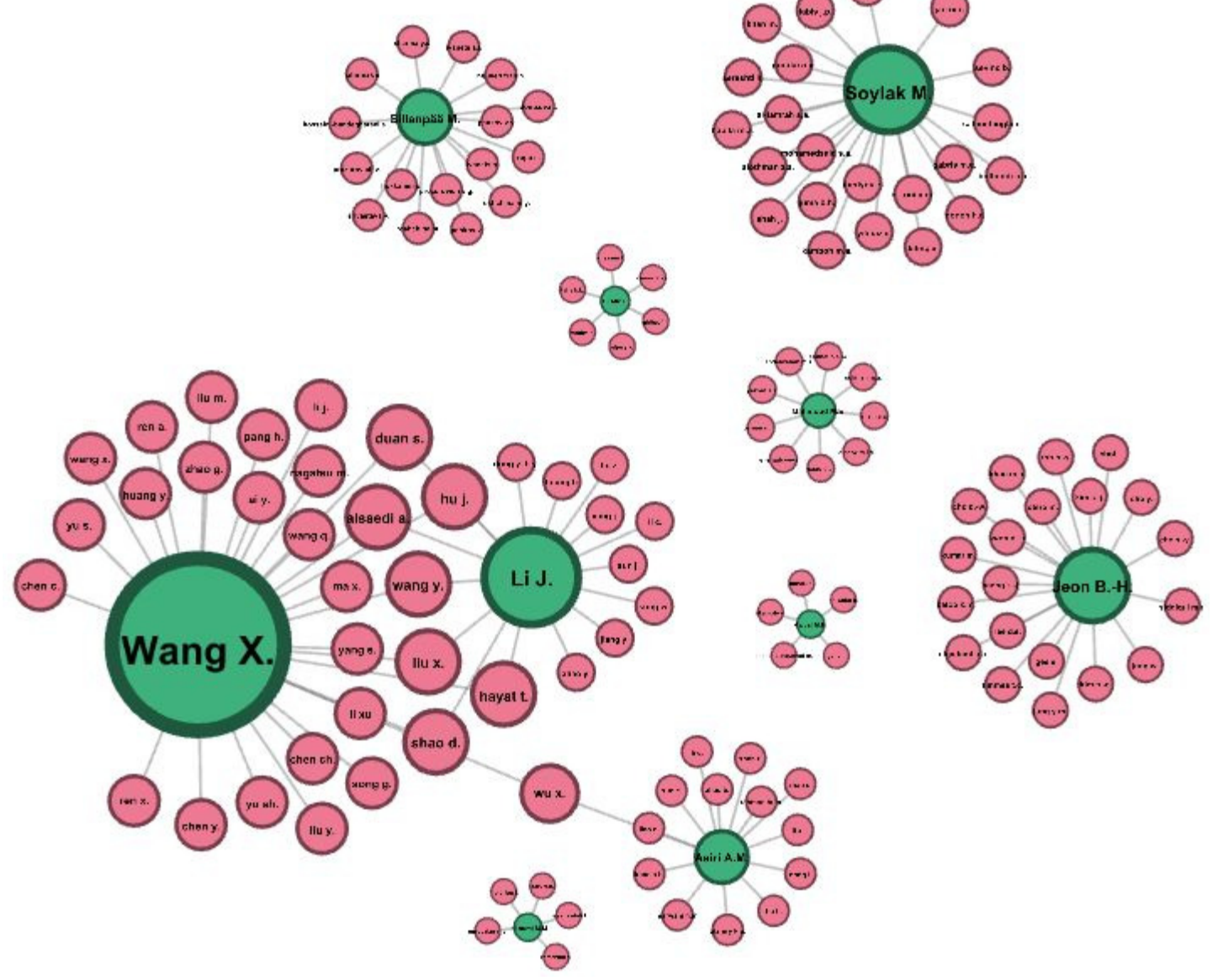

Figure 4. Collaboration network of top-10 prolific authors.

Table 5. Top 10 productive Authors.

\begin{tabular}{|c|c|c|c|c|c|c|c|}
\hline Rank & Author & Institution & $\begin{array}{c}\text { No of } \\
\text { Research } \\
\text { Articles }\end{array}$ & $\begin{array}{c}\text { Total } \\
\text { Citations }\end{array}$ & $\begin{array}{c}\text { h- } \\
\text { Index }\end{array}$ & CI & $\begin{array}{l}\text { Start } \\
\text { Year }\end{array}$ \\
\hline 1 & Wang X. & Chinese Academy of Sciences & 7 & 1839 & 7 & 6 & 2011 \\
\hline 2 & Li J. & Chinese Academy of Sciences & 6 & 1439 & 6 & 7 & 2013 \\
\hline 3 & Sillanpää M. & LUT University, Finland & 5 & 359 & 3 & 5 & 2013 \\
\hline 4 & Soylak M. & Erciyes University, Turkey & 5 & 197 & 5 & 6 & 2016 \\
\hline 5 & Mahmoud M.E. & $\begin{array}{c}\text { Alexandria University, } \\
\text { Egypt }\end{array}$ & 5 & 55 & 5 & 5 & 2016 \\
\hline 6 & Lakouraj M.M. & University of Mazandara, Iran & 4 & 210 & 4 & 3 & 2014 \\
\hline 7 & Jeon B.-H. & Hanyang University, South Korea & 4 & 139 & 4 & 7 & 2014 \\
\hline 8 & Awual M.R. & $\begin{array}{c}\text { Japan Atomic Energy Agency, } \\
\text { Japan }\end{array}$ & 3 & 424 & 3 & 3 & 2014 \\
\hline 9 & Asiri A.M. & $\begin{array}{c}\text { King Abdulaziz University, Saudi } \\
\text { Arabia }\end{array}$ & 3 & 30 & 3 & 7 & 2014 \\
\hline 10 & El Mir L. & Gabes University, Tunisia & 3 & 10 & 2 & 4 & 2015 \\
\hline $\begin{array}{l}\text { Total/ } \\
\text { Average }\end{array}$ & & & 42 & 4602 & 4 & 5 & 2014 \\
\hline
\end{tabular}

In order to identify authors' influence, the collaboration network of the top-10 authors was visualized using Gephi software. Before being entered in Gephi, the Scopus dataset 
was processed in Excel, so that all co-authors' names to be coupled with their corresponding Scopus ID, thus avoiding evaluating co-authors who shared the same name but different Scopus' IDs as one. Gephi's ForceAtlas algorithm was run on the dataset and the resulted visualization is presented in Figure 4. The authors are represented with green colored nodes and are connected, through links (edges in Gephi's terminology), with their respective co-authors, represented with pink colored nodes. The thicker the edge linking two nodes, the more intensive was the collaboration between these two nodes. From the visualization it is easy to understand that typically all authors published papers more frequently with certain co-authors. The authors ranked in the first two places Wang X. and Li J., both from the Chinese Academy of Science, had three in common publications and shared seven co-authors. Wang X. also shared one co-author with Asiri A.M., from King Abdulaziz University of Saudi Arabia. The rest of the authors did not share any co-authors with one another. Eigenvector is another micro-level metrics of centrality used to analyze the co-authorship network and identify the influence of an author within the network. An author, which is connected to many other co-authors that are themselves well-connected, has a high eigenvector centrality and an author connected to few co-authors who also have a few connections has a much lower score [65]. Thus, in the representation in Figure 4 the nodes were sized in respect to the value of the of the eigenvector centrality of each author and co-author in the network structure. Nodes' labels font sizes were in accordance with the nodes' size. Considering the eigenvector centrality values (given in parentheses), Wang X. (1) and Li J. (0.47) were ranked first, as those two authors shared many co-authors, while Soylak M. (0.40) followed, as he exceeded the rest of the authors, demonstrating high number of both publications and CI, as noted in Table 5's data. The collaboration network of the top 10 authors had (i) a graph density [65] of 0.014, meaning that only $1.4 \%$ of the possible connections in the network occurred and (ii) an average degree [65] of 2, meaning that only two, on average, authors were connected in the network As a result, such analysis can provide the basis for the possibility to optimize collaboration between main and non-mainstream authors, and to strengthen and tighten the existing collaborations, so as to build a stronger network in the future [66].

\subsection{Top 10 Co-Occurred Authors' Keywords}

To obtain the 10 keywords that were most frequently used within the dataset of the 214 publications, the network based on authors' keywords was constructed using VOSviewer software. VOSviewer was selected in this case as it has a ready to use authors' keywordsco-occurrence analysis tool for Scopus datasets. Our dataset consisted of 586 keywords. We set the minimum of two occurrences as the threshold and VOSviewer analysis resulted to 102 keywords. For each of the 102 keywords, VOSviewer calculated the total strength of co-occurrence links with other keywords of the dataset, and we selected the 10 keywords with the greatest total link strength for visualization, so that we can focus on the major research streams. VOSviewer has the option to handle similar keywords as one, e.g., "heavy metals" and "heavy metal", but we chose not to apply this process to the dataset so as to identify the keywords' variations that authors had chosen to index their publications with and visualize the frequency of their appearance, as well as their key role in the calculated co-occurrence network.

VOSviewer authors' keywords network is based on a distance-directed visualization. The size of the nodes and their labels is proportional to the frequency of keywords. The higher the frequency, the larger is the size. The co-occurrence of the terms determines the width of the links: the higher the co-occurrence, the thicker the line. The color of a keyword indicates the cluster it belongs to. The clusters of related keywords appear in the network, indicating their relatedness in terms of relevant publications. Distances between keywords indicate relatedness of keywords in terms of co-occurrence links. The closer the relatedness the smaller is the distance between the keywords, in the map [54].

From the representations in Figure 5, we can understand that the more general terms were more frequently selected by the authors' as keywords for their publications. The term 
"adsorption" dominated the graph, presenting the highest occurrence value (54), followed by the term "cobalt" (27). However, note that instead of those terms, authors' indexed their publications using, respectively, the terms of "sorption" (13) and "Co(II)" (17). The term "heavy metals" (20) also stood out in the graph and then followed the general terms referring to kinetics and isotherm studies of adsorption, indexed in descending frequencies as "kinetics" (12), "isotherm" (10), and "kinetic" (6). The general term "nanoparticle" (7) was the most frequently used term to index nano-adsorbents' publications, while, the term "graphene oxide" (10) was the only specific term, characterizing the type of the nanoadsorbent, included in the map of the top-10 co-occurred authors' keywords, co-existing (in the same cluster) with the major terms "adsorption" and "cobalt", demonstrating thus, the importance of this type of carbon-based nano-adsorbent for cobalt removal from wastewater.

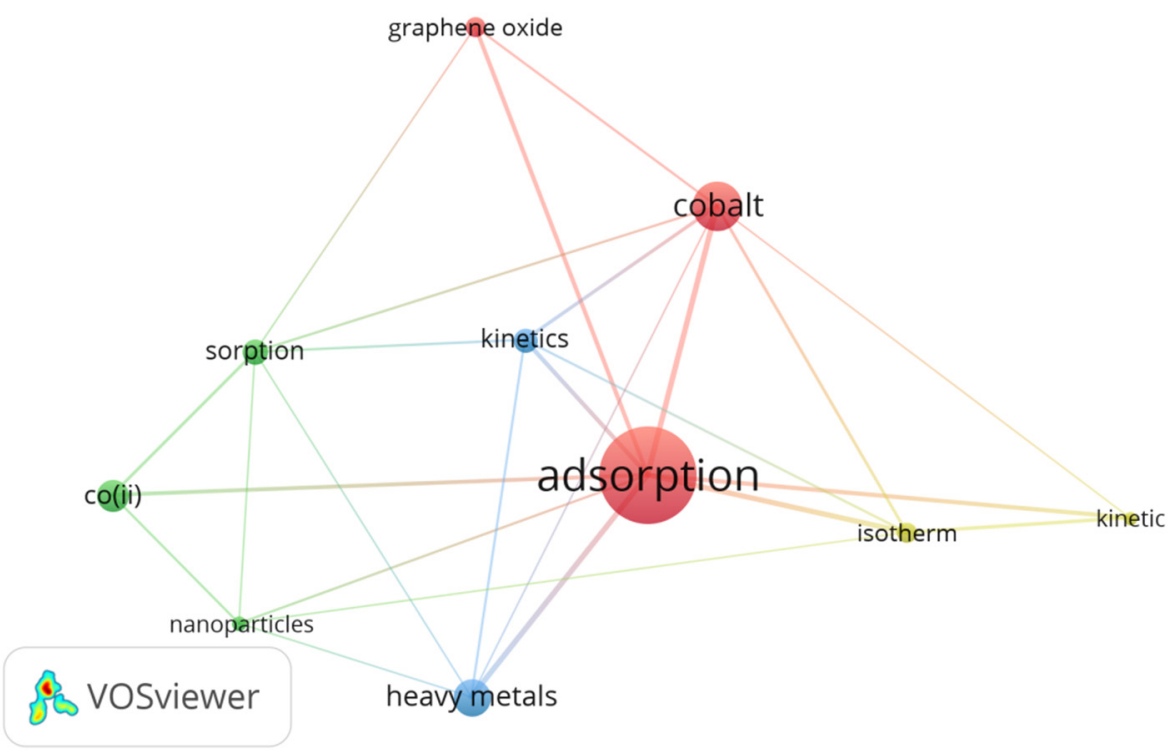

Figure 5. Network visualization of top 10 co-occurring authors' keywords.

Authors' keywords analysis is an under-researched but emerging area of scientific information [67]. The findings of such authors' keywords analysis can not only help identifying major research topics but can also enhance the quality of communication between the authors and users of the scientific information. Though such analysis, authors can benefit of a more effective keywords' selection and retrievers of scientific information can identify more easily the proper keywords in researching for a particular topic.

\subsection{Top 10 Cited Research Articles}

The dataset of the 214 publications was further analyzed in respect to the number of citations the publications have received. The top 10 cited articles were identified and ranked in descending order in Table 6 . The top 10 cited publications were made in scientific journals with impact factor in the range of 10.652 to 3.333. Nine out of 10 publications were published in journals ranked in the 1st quartile (Q1) and one in the 2nd (Q2) (journals' impact factor and its corresponding quartile ranking is given in parenthesis in Table 6, only for journals not included in Table 4's data). Three out of the 10 publications, presented in Table 6, were not identified in the preceded assessments of this study, namely publications ranked in 5th, 6th, and 7th place, written by authors originated from institutions located in Romania/France, Taiwan, and Turkey, respectively. 
Table 6. Top 10 cited research articles.

\begin{tabular}{|c|c|c|c|c|c|}
\hline Rank & Title & Authors & Journal & $\begin{array}{c}\text { Total } \\
\text { Citations }\end{array}$ & $\begin{array}{c}\text { Publication } \\
\text { Year }\end{array}$ \\
\hline 1 & $\begin{array}{l}\text { Few-layered graphene oxide } \\
\text { nanosheets as superior sorbents } \\
\text { for heavy metal ion pollution } \\
\text { management }\end{array}$ & $\begin{array}{l}\text { Zhao G., Li J., Ren X., } \\
\text { Chen C., Wang X. }\end{array}$ & $\begin{array}{l}\text { Environmental } \\
\text { Science and } \\
\text { Technology }\end{array}$ & 1223 & 2011 \\
\hline 2 & $\begin{array}{l}\text { Adsorption of divalent heavy } \\
\text { metal ions from water using } \\
\text { carbon nanotube sheets }\end{array}$ & $\begin{array}{l}\text { Tofighy M.A., } \\
\text { Mohammadi T. }\end{array}$ & $\begin{array}{l}\text { Journal of } \\
\text { Hazardous } \\
\text { Materials }\end{array}$ & 485 & 2011 \\
\hline 3 & $\begin{array}{c}\text { Simultaneous removal of } \\
\text { heavy-metal ions in wastewater } \\
\text { samples using nano-alumina } \\
\text { modified with } \\
\text { 2,4-dinitrophenylhydrazine }\end{array}$ & $\begin{array}{l}\text { Afkhami A., } \\
\text { Saber-Tehrani M., } \\
\text { Bagheri H. }\end{array}$ & $\begin{array}{l}\text { Journal of } \\
\text { Hazardous } \\
\text { Materials }\end{array}$ & 355 & 2010 \\
\hline 4 & $\begin{array}{c}\text { Synthesis of magnetite/graphene } \\
\text { oxide composite and application } \\
\text { for cobalt(II) removal }\end{array}$ & $\begin{array}{c}\text { Liu M., Chen C., Hu J., } \\
\text { Wu X., Wang X. }\end{array}$ & $\begin{array}{l}\text { Journal of Physical } \\
\text { Chemistry C } \\
(4.189 / \mathrm{Q} 2) *\end{array}$ & 337 & 2011 \\
\hline 5 & $\begin{array}{l}\text { Synthesis and characterization of } \\
\text { kaolinite-supported zero-valent } \\
\text { iron nanoparticles and their } \\
\text { application for the removal of } \\
\text { aqueous } \mathrm{Cu}^{2+} \text { and } \mathrm{Co}^{2+} \text { ions }\end{array}$ & $\begin{array}{l}\text { Üzüm Ç., Shahwan T., } \\
\text { Eroğlu A.E., Hallam } \\
\text { K.R., Scott T.B., } \\
\text { Lieberwirth I. }\end{array}$ & $\begin{array}{l}\text { Applied Clay } \\
\text { Science } \\
(4.605 / Q 1) *\end{array}$ & 272 & 2009 \\
\hline 6 & $\begin{array}{l}\text { Modified SBA-15 mesoporous } \\
\text { silica for heavy metal ions } \\
\text { remediation }\end{array}$ & $\begin{array}{l}\text { Mureseanu M., Reiss } \\
\text { A., Stefanescu I., } \\
\text { David E., Parvulescu } \\
\text { V., Renard G., Hulea V. }\end{array}$ & $\begin{array}{l}\text { Chemosphere } \\
(5.778 / \mathrm{Q} 1)^{*}\end{array}$ & 230 & 2008 \\
\hline 7 & $\begin{array}{l}\text { Magnetic chitosan nanoparticles: } \\
\text { Studies on chitosan binding and } \\
\text { adsorption of Co(II) ions }\end{array}$ & $\begin{array}{l}\text { Chang Y.-C., Chang } \\
\text { S.-W., Chen D.-H. }\end{array}$ & $\begin{array}{l}\text { Reactive and } \\
\text { Functional } \\
\text { Polymers } \\
(3.333 / \mathrm{Q} 1)^{*}\end{array}$ & 205 & 2006 \\
\hline 8 & $\begin{array}{c}\text { Removal of heavy metals from } \\
\text { aqueous solutions by succinic } \\
\text { anhydride modified mercerized } \\
\text { nanocellulose }\end{array}$ & $\begin{array}{l}\text { Hokkanen S., Repo E., } \\
\text { Sillanpää M. }\end{array}$ & $\begin{array}{l}\text { Chemical } \\
\text { Engineering } \\
\text { Journal }\end{array}$ & 182 & 2013 \\
\hline 9 & $\begin{array}{c}\text { Functional ligand anchored } \\
\text { nanomaterial based facial } \\
\text { adsorbent for cobalt(II) detection } \\
\text { and removal from water samples }\end{array}$ & $\begin{array}{c}\text { Shahat A., Awual M.R., } \\
\text { Naushad M. }\end{array}$ & $\begin{array}{l}\text { Chemical } \\
\text { Engineering } \\
\text { Journal }\end{array}$ & 181 & 2015 \\
\hline 10 & $\begin{array}{l}\text { Removal of cobalt ions from } \\
\text { aqueous solution by an amination } \\
\text { graphene oxide nanocomposite }\end{array}$ & $\begin{array}{l}\text { Fang F., Kong L., } \\
\text { Huang J., Wu S., } \\
\text { Zhang K., Wang XU., } \\
\text { Sun B., Jin Z., Wang J., } \\
\text { Huang X.-J., Liu J. }\end{array}$ & $\begin{array}{l}\text { Journal of } \\
\text { Hazardous } \\
\text { Materials }\end{array}$ & 166 & 2014 \\
\hline
\end{tabular}

\subsubsection{Distribution of Total Citations over Time Periods for the Top 10 Cited} Research Articles

The list of the 10 most cited articles consisted of articles published between years 2006 and 2015 and had citations in the range of 1225 to 166, up to 16 April 2021. Regardless the publication year, most of 10 top cited publications (nine out of 10) received the majority of citations between 2016-2020, as presented in Figure 6, indicating thus the growing interest towards the topic over the last five years, as was also observed for the same time span in Figure 1, where the growth of the research papers related to nano-adsorbents for $\mathrm{Co}(\mathrm{II})$ removal from wastewater, was presented. 


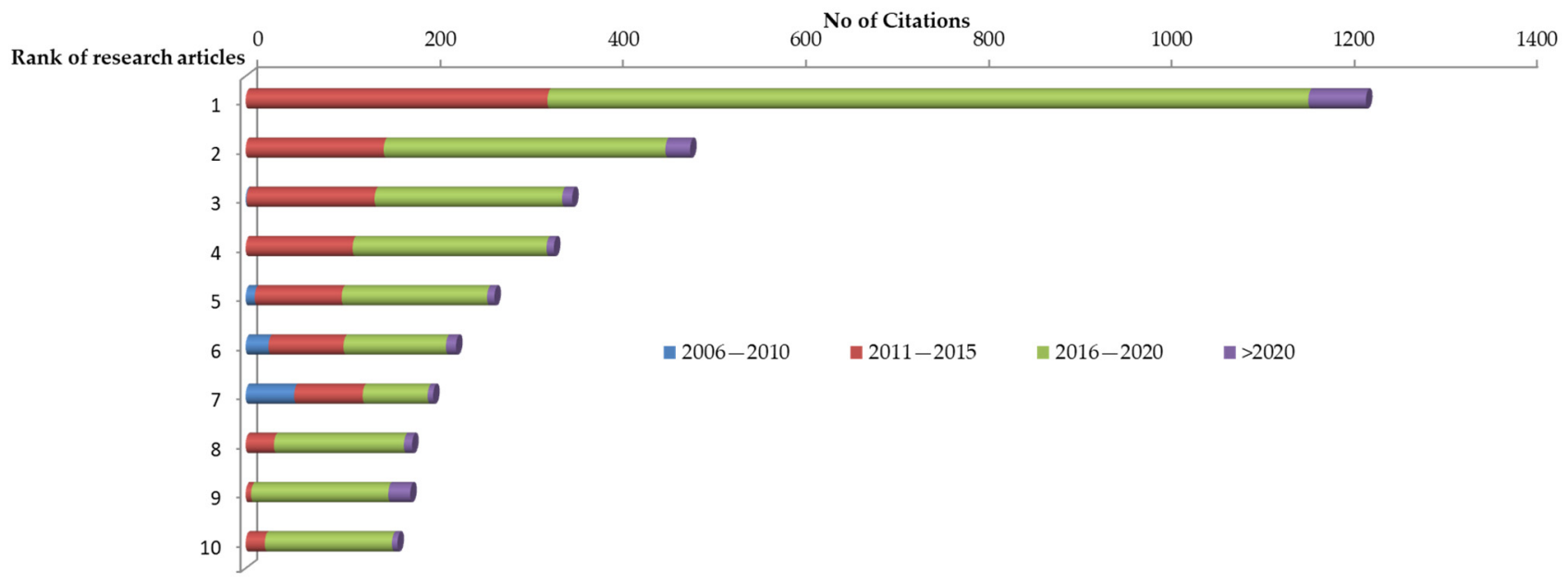

Figure 6. Distribution of total citations over four time periods for the 10 most cited articles.

\subsubsection{Co-Authorship Network of the Top 10 Cited Research Articles}

For exploring the co-authorship network of the most cited publications, Gephi's visualization was applied. The network was deployed using ForceAtlas layout algorithm. To make the graph visually readable, publications' nodes were connected to their respective authors' nodes. To facilitate the network's interpretation, publications' nodes were colored in green, sized, and labeled according to each publication's ranking order, while authors' nodes were labeled with each author's name and colored according to the authors' affiliation. As it is easily understood from the visualization, presented in Figure 7, six out of ten publications were made by authors of the same institution, three of the rest four publications shared co-authorship affiliated from different countries, while only two publications were identified to have two of their authors in common, namely, publications ranked in 1st and 4th place, both affiliated by the Chinese Academy of Science.

The diverse focus of these top 10 cited publications, the difference in authors' affiliations and time span of publications' year, could be the obvious reasons for why these top 10 cited publications appeared to represent a sparse and weakly interconnected network of co-authors. Nevertheless, there were two publications, focusing on the same type of cobalt nano-adsorbents, produced by authors from the same institution, published three years apart, that were still not connected through their co-authors' network, namely, the publications ranked in 1st and 10th place.

\subsubsection{Co-Citation Network of the Top 10 Cited Research Articles}

Trying to understand beyond the obvious reasons of such realization, the co-citation network, or in other words, the network of the references used by these 10 toped cited publications was also investigated, after being visualized, using the same approach as before. Again, the publications were represented with green colored nodes; and their sizes were manually enlarged, in respect to their ranking position, to facilitate the representation. Each publication was linked with arrowed edges, pointing to the corresponding references (pink colored nodes). To facilitate reading of the graph, the references that were shared between different publications were colored red. The publications that referenced one another were also linked through pointed edges. Even though the same layout was used as in Figure 7 representation, the position of the 10 most cited publications in this network representation was different, compared to that of Figure 7, as the force-directed layout, places each node depending on the other nodes of each particular analysis and turns structural proximities into visual proximities, by pushing, in general, highly connected nodes at the periphery and putting less connected nodes more central [68]. Furthermore, as the "attractive and repulsive" mechanism of the algorithm can be manually controlled by the user, we stopped the layout when a clear visual interpretation of the networks' 
structure could be accomplished, that was when co-cited nodes where not overlapped and their links could be easily identified.
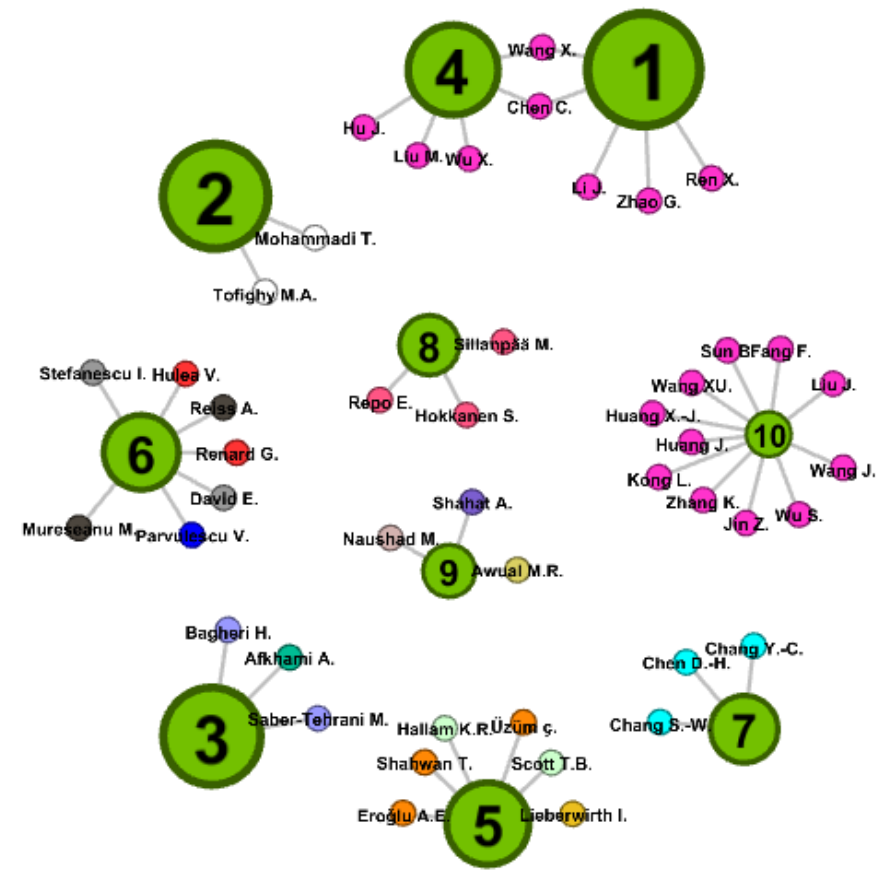

- Chinese Academy of Sciences

Iran University of Science and Technology

Islamic Azad University, Iran

- Bu-Ali Sina University, Iran

- Izmir Institute of Technology, Turkey

University of Bristol, UK

Max Planck Institute, Germany

- University of Craiova, Romania

- National Institute of Cryogenics \& Isotope Separation, Romania

- Institute of Physical Chemistry, Romania

- CNRS, France

- National Cheng Kung University, Taiwan

- LUT University, Finland

- Suez University, Egypt

- King Saud University, Saudi Arabia

- Japan Atomic Energy Agency

Figure 7. Authors' network visualization and corresponding affiliations of the top 10 cited publications.

In this context, the visualization in Figure 8 helped us realized that even though the publications ranked in 1st and 10th place did not share co-authorship, the 10th was placed in close proximity to the 1st publication, as it referenced the 1st, indicating that the preceded 1st ranked publication had been taken into consideration by the particular research group and received the appropriate peer recognition. No other direct reference was identified between the 10 top cited publications. However, the 10th publication shared three other references with 1st publication, had one reference in common with 2nd and one reference in common with 3rd publication, while the 9th publication, which was published one year later than the 10th, was also identified to have one reference in common with 10th publication.

Co-occurrence of citations is a tool also used to identify fundamental literature on a certain topic, as when research groups cite a common set of papers, these co-citations indicate works that may contain key concept equations, experiments, or results and thus are usually frequently cited, in terms of bulk citations [46]. That is clearly the case of reference (i) corresponding to the fundamental work of Langmuir (1918), cited 14,441 times, where the Langmuir's adsorption model was presented. In reviewing (ii)-(vii) co-citations, shared in Figure 8's network: (ii) Netzer et al. (1984) paper, cited 229 times, was referring to cobalt removal from wastewater using activated carbon, effective adsorbent for removing metallic species from wastewater, though not extensively applied due to its high cost [69], (iii) Yüzer et al. (2008), cited 70 times, was used in reference to the forms of cobalt in various $\mathrm{pH}$ values. (v) Bhatnagar et al. (2010) work on lemon peels bio-sorbent of $25.6 \mathrm{mg} / \mathrm{g}$ adsorption capacity, cited 250 times, was used to compare nano-adsorbents' capacity for $\mathrm{Co}$ (II) removal to other sorbents. While, the rest of the co-cited publications were used to cite more general aspects of research, such as the presence of heavy metals in various industrial influents (Yang et al. 2009, cited 345 times) and the various materials that have been used as heavy metals' adsorbents (Tan et al. 2009, cited 320 times and Fonseca et al. 2011, cited 50 times). 


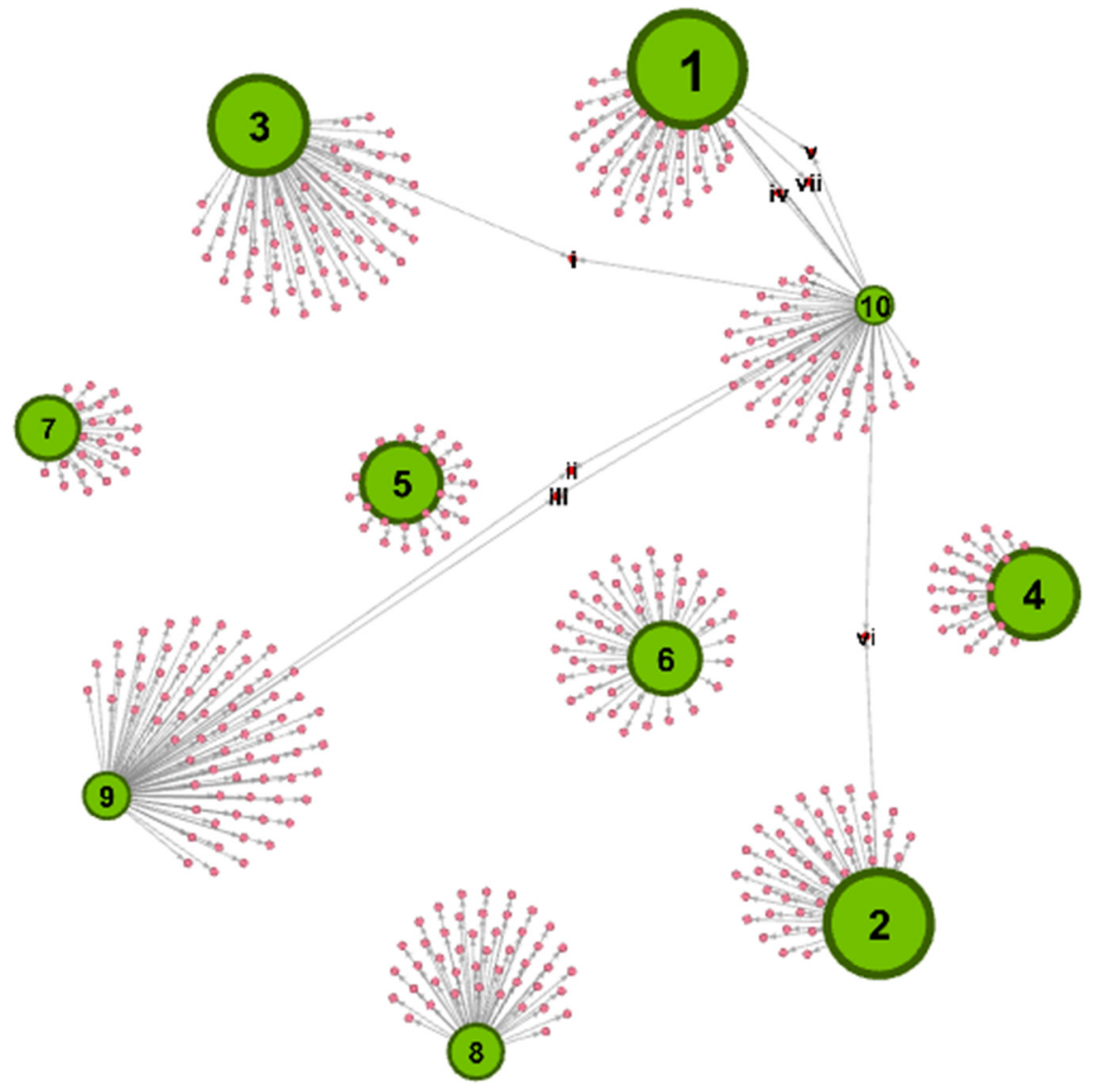

i Langmuir, I. The adsorption of gases on plane surfaces of glass, mica and platinum (1918) Journal of the American Chemical Society, 40 (9), pp. 1361-1403. Cited 14,441 times.

ii Netzer, A., Hughes, D.E. Adsorption of copper, lead and cobalt by activated carbon (1984) Water Research, 18 (8), pp. 927-933. Cited 229 times.

iii Yüzer, H., Kara, M., Sabah, E., Çelik, M.S. Contribution of cobalt ion precipitation to adsorption in ion exchange dominant system (2008) Journal of Hazardous Materials, 151 (1), pp. 33-37. Cited 70 times.

iv Tan, X., Fan, Q., Wang, X., Grambow, B. Eu(III) sorption to TiO2 (anatase and rutile): Batch, XPS, and EXAFS studies (2009) Environmental Science and Technology, 43 (9), pp. 3115-3121. Cited 320 times.

v Bhatnagar, A., Minocha, A.K., Sillanpää, M. Adsorptive removal of cobalt from aqueous solution by utilizing lemon peel as biosorbent (2010) Biochemical Engineering Journal, 48 (2), pp. 181-186. Cited 250 times.

vi Yang, S., Li, J., Shao, D., Hu, J., Wang, X. Adsorption of Ni(II) on oxidized multi-walled carbon nanotubes: Effect of contact time, $\mathrm{pH}$, foreign ions and PAA (2009) Journal of Hazardous Materials, 166 (1), pp. 109-116. Cited 345 times.

vii Fonseca, B., Figueiredo, H., Rodrigues, J., Queiroz, A., Tavares, T. Mobility of $\mathrm{Cr}, \mathrm{Pb}, \mathrm{Cd}, \mathrm{Cu}$ and $\mathrm{Zn}$ in a loamy sand soil: A comparative study (2011) Geoderma, 164 (3-4), pp. 232-237. Cited 50 times.

Figure 8. Citations' network visualization and corresponding co-cited references of the top 10 cited publications. 


\subsubsection{Cobalt Adsorption Insights of the Top 10 Cited Research Articles}

Trying to understand even further what made those 10 top cited articles being highly cited by their peers, a comprehensive comparison of the nano-adsorbents studied in these 10 articles is reported in Table 7.

As understood from the data, presented in Table 7, the list of the top 10 cited articles contains carbon, alumina, silica, iron, chitosan, and cellulose-based nanomaterials. Most of the nano-adsorbents have been prepared, through various chemical modification processes, so as to achieve cobalt adsorption capacities higher than their corresponding bulk materials. Amongst the different nano-adsorbents, graphene oxide is the most pertinent, as 3 out of 10 publications are focusing on this material. All nano-adsorbents were tested for cobalt removal in ambient temperature and according to the available results, the experimental data agreed well with the Langmuir isotherm (correlation coefficient, $R^{2}>0.95$ ). When adsorption kinetics was included in the studies, it was observed that the experimental data agreed with the pseudo-first- or pseudo-second-order kinetic model. The nano-adsorbents operated within the $\mathrm{pH}$ range of 4.8-7 (real wastewater demonstrate $\mathrm{pH}$ values close to 6 , due to the dissociation of $\mathrm{CO}_{2}$ ), while two of the nano-adsorbents namely the kaolinite supported iron nanoparticles and the ligand anchored functional silica nanomaterial, achieved optimum conditions at $\mathrm{pH}$ values of 8 and 8.5 , respectively. These observations can be explained on the basis that in aqueous media up to $\mathrm{pH}$ values of 8 , the dominant chemical form of cobalt is $\mathrm{Co}^{2+}$ and above $\mathrm{pH}$ values of 8.5 , the chemical forms of $\mathrm{Co}^{2+}$ and $\mathrm{CoOH}^{+}$become prominent and precipitation of $\mathrm{Co}(\mathrm{OH})_{2}$ begins to form at $\mathrm{pH}>8.5$, and reaches maximum at $\mathrm{pH}$ values of 9.50 [70]. Therefore, the sorption of $\mathrm{Co}$ (II) by those two nano-adsorbents is accomplished by sorption and precipitation.

In terms of the specific surface area, it is interesting to note that among the available documented values, silica-based nano-adsorbents exhibited higher specific surface areas, compared to the iron and alumina-based nanoparticles. The high specific surface area does not always correspond to a higher adsorption capacity [71], as noted in the case of the functionalized SBA-15 silica nano-absorbent. However, as the adsorption capacity is to a large extent a function of the nano-adsorbents' specific surface area [71], the ligandanchored functional silica nanomaterial, that exhibited the highest surface area among the top 10 cited articles, also achieved the highest adsorption capacity among these 10 research works and one of the highest values reported in the literature for cobalt removal. Note also the case of aminated graphene oxide nanocomposite, as the adsorbent not only achieved a similar high adsorption capacity $(116.35 \mathrm{mg} / \mathrm{g})$ for cobalt, but also demonstrated a very quick adsorption property for the removal of $\mathrm{Co}$ (II) ions, as more than $90 \%$ of $\mathrm{Co}$ (II) ions was observed to have been removed within $5 \mathrm{~min}$ [72].

Moreover, note that many of the 10 most cited articles have dealt with issues that still remain a challenge for the real application of the nano-adsorbents to the $\mathrm{Co}$ (II) ions removal from aqueous solutions in large-scale operations [35]. Thus, in respect to competitive adsorption, graphene oxide nanosheets were tested in the presence of humic substances, which are present widely in the environment and results showed that the presence of humic acid reduces $\mathrm{Co}$ (II) sorption at $\mathrm{pH}<8$, and at $\mathrm{pH}>8$ no obvious difference was found [73]. The selectivity of $\mathrm{Co}$ (II) removal against ions commonly found in real wastewater samples, was also tested in two of the papers and was found to reduce $\mathrm{Co}(\mathrm{II})$ removal by $31.6 \%$ in the case of the functionalized SBA-15 silica [74], while Co(II) removal was not affected in the case of functional ligand anchored on mesoporous inorganic silica [75].

To make the nano-adsorbent economic affordable for large scale wastewater applications its regeneration plays key role factor, as regeneration restores the original adsorption capacity of the adsorbent, and it also enables the recovering of cobalt. According to Table 7 data, in studies where such treatment was applied, acid treatment was found to enable regeneration of the nano-adsorbents and when regeneration was coupled with reusability experiments the regenerated nano-adsorbents worked without significant loss of its original performances [74-77]. 
Table 7. Cobalt adsorption insights of the top 10 cited research articles.

\begin{tabular}{|c|c|c|c|c|c|c|c|c|c|c|c|c|c|c|}
\hline $\begin{array}{c}\text { Nano- } \\
\text { Adsorbent }\end{array}$ & Preparation & Size (nm) & $\begin{array}{l}\text { Surface } \\
\text { Area } \\
\left(\mathrm{m}^{2} / \mathrm{g}\right)\end{array}$ & $\begin{array}{l}\text { Initial } \\
\text { Co(II) } \\
\mathrm{mg} / \mathrm{L}\end{array}$ & $\begin{array}{c}\text { Maximum } \\
\text { Adsorption } \\
\text { Capacity } \\
(\mathrm{mg} / \mathrm{g})\end{array}$ & Time & $\mathrm{pH}$ & $\begin{array}{l}\text { Temperature } \\
\text { (K) }\end{array}$ & $\begin{array}{l}\text { Kinetic } \\
\text { Model }\end{array}$ & Isotherm & $\begin{array}{l}\text { Competitive } \\
\text { Adsorption }\end{array}$ & Regeneration & $\begin{array}{l}\text { Reusability } \\
\text { Tested }\end{array}$ & $\begin{array}{l}\text { Rank/ } \\
\text { Ref. }\end{array}$ \\
\hline $\begin{array}{l}\text { Graphene } \\
\text { oxide } \\
\text { nanosheets }\end{array}$ & $\begin{array}{l}\text { Modified } \\
\text { Hammer } \\
\text { method }\end{array}$ & $\sim 0.87$ & - & 30 & 68.2 & $24 \mathrm{~h}$ & 6 & 303 & - & Langmuir & Humic acid & - & - & $\begin{array}{c}1 \\
{[36]}\end{array}$ \\
\hline $\begin{array}{l}\text { Carbon } \\
\text { nanotubes } \\
\text { sheets }\end{array}$ & Oxidation & $30-40$ & - & 1200 & 85.74 & $20 \mathrm{~h}$ & 7 & 298.15 & $\begin{array}{l}\text { pseudo-1st } \\
\text { order }\end{array}$ & Langmuir & - & - & - & $\begin{array}{c}2 \\
{[78]}\end{array}$ \\
\hline $\begin{array}{l}\text { Nano-alumina } \\
\text { modified }\end{array}$ & $\begin{array}{l}\text { Chemical } \\
\text { modification }\end{array}$ & $68-85$ & 30.38 & 150 & 41.66 & $90 \mathrm{~min}$ & 5.5 & 298.15 & - & Langmuir & - & $\begin{array}{c}\text { Methanol with } \\
\mathrm{HNO}_{3}\end{array}$ & Yes & $\begin{array}{c}3 \\
{[76]}\end{array}$ \\
\hline $\begin{array}{c}\text { Kaolinite- } \\
\text { supported } \\
\text { zero-valent } \\
\text { iron } \\
\text { nanoparticles }\end{array}$ & $\begin{array}{l}\text { Borohydride } \\
\text { reduction }\end{array}$ & $10-80$ & 24.7 & 100 & 25 & $\begin{array}{l}120 \\
\text { min }\end{array}$ & 8 & 298.15 & - & - & - & - & - & $\begin{array}{c}5 \\
{[70]}\end{array}$ \\
\hline $\begin{array}{l}\text { Functionalized } \\
\text { SBA-15 silica }\end{array}$ & $\begin{array}{l}\text { Two-step } \\
\text { post-grafting } \\
\text { procedure }\end{array}$ & $\begin{array}{c}7.8 \\
\text { (mean) }\end{array}$ & 368 & 235.97 & 19 & $30 \mathrm{~min}$ & 4.8 & 298.15 & - & - & $\begin{array}{c}\mathrm{Cu}^{2+}, \mathrm{Ni}^{2+}, \\
\mathrm{Zn}^{2+}\end{array}$ & $\mathrm{HCl}$ elution & Yes & $\begin{array}{c}6 \\
{[74]}\end{array}$ \\
\hline $\begin{array}{c}\text { Magnetic } \\
\text { chitosan } \\
\text { nanoparticles }\end{array}$ & $\begin{array}{l}\text { Coprecipitation } \\
\text { hydrother- } \\
\text { mal } \\
\text { treatment }\end{array}$ & $\begin{array}{c}13.5 \\
\text { (mean) }\end{array}$ & - & 1500 & 27.4 & $1 \mathrm{~h}$ & 5.5 & 298.15 & - & Langmuir & - & - & - & $\begin{array}{c}7 \\
{[80]}\end{array}$ \\
\hline $\begin{array}{c}\text { Succinic } \\
\text { anhydride- } \\
\text { modified } \\
\text { mercerized } \\
\text { nanocellulose }\end{array}$ & $\begin{array}{l}\text { mercerization } \\
\text { treatment } \\
\text { and } \\
\text { modification }\end{array}$ & 10-100 & - & 590 & 78 & $24 \mathrm{~h}$ & 5 & 298.15 & - & Langmuir & - & $\begin{array}{c}\mathrm{HNO}_{3} \text { and } \\
\text { ultrasonic } \\
\text { treatment }\end{array}$ & Yes & $\begin{array}{c}8 \\
{[77]}\end{array}$ \\
\hline $\begin{array}{l}\text { Functional } \\
\text { ligand } \\
\text { anchored on } \\
\text { mesoporous } \\
\text { inorganic silica }\end{array}$ & $\begin{array}{l}\text { Building- } \\
\text { block } \\
\text { approach }\end{array}$ & $10-50$ & 569 & 75.10 & 157.73 & $30 \mathrm{~min}$ & 8.5 & 298.15 & - & Langmuir & $\begin{array}{c}\mathrm{Na}^{+}, \mathrm{K}^{+}, \mathrm{Li}^{+}, \\
\mathrm{Ca}^{2+}, \mathrm{Ba}^{2+}, \\
\mathrm{Mg}^{2+}, \mathrm{Pb}^{2+}, \\
\mathrm{Zn}^{2+}, \mathrm{Cd}^{2+}, \\
\mathrm{Fe}^{3+}, \mathrm{Al}^{3+}{ }^{3+}\end{array}$ & $\mathrm{HCl}$ elution & Yes & $\begin{array}{c}9 \\
{[75]}\end{array}$ \\
\hline $\begin{array}{l}\text { Aminated } \\
\text { graphene oxide }\end{array}$ & Oxidation & - & 320 & 90 & 116.35 & $5 \min$ & 6 & 298 & $\begin{array}{c}\text { pseudo-1st } \\
\text { order }\end{array}$ & Langmuir & & $\mathrm{HNO}_{3}$ elution & - & $\begin{array}{c}10 \\
{[72]}\end{array}$ \\
\hline
\end{tabular}


The insights of these 10 highly cited publications feature not only the trends of research made on the topic but also how the development of these materials have taken place. The publication on aminated graphene-oxide for instance, was the only one identified, through the co-citation analysis and visualization in Figure 8, to direct reference the work on graphene-oxide nanosheets, ranked in the 1st place of the 10 top cited articles. This finding leads to the realization that this particular research group published a work on 15 April 2014, based on an earlier, highly cited research article, which had received 146 citations by 15 April 2014, and in this publication, a nano-adsorbent with one of the highest capabilities for cobalt removal of today's materials is presented. Thus, what the cobalt adsorption insights of the top 10 cited publications made clear is that the bibliometric network analysis and visualization can put articles' citations to a different perspective, helping in capturing the value of certain citations to the evolution of the research on the topic.

\section{Conclusions}

In this study, research articles, indexed in a Scopus database until the end of 2020, on the topic of nano-adsorbents for $\mathrm{Co}$ (II) removal from wastewater were assessed, and the leading journals, institutions, authors, publications, scientific terms, and cooperation patterns were revealed by coupling conventional bibliometric indicators with social network analysis tools.

Chemical Engineering Journal was identified as the most prolific journal in the field, King Saud University of Saudi Arabia, Chinese Academy of Science, and LUT University of Finland were found to control information flows in the network of the most prolific institutions, while co-operation between China, Saudi Arabia, and United States was also identified. Published research articles of the years 2014-2020 added up to $83.6 \%$ of the total of 214 relevant articles, and even though the growth of the relevant research papers is not in its exponential phase, the trend is definitely increasing and that can lead to greater focus on the subject in the forthcoming years.

Considering the expansion of science visualization tools and their recent incorporation, in various forms, into the bibliometric databases (e.g., SciVal tool, not as broadly used yet as it demands extra institutional subscription, was recently incorporated to Scopus database, enabling research performance visualization), then the approach applied in this study and its findings can help in deepening the understanding and interpretation of the visual analytics, as such tools, besides their ready or easy to use interfaces, still demand scientists keen to structure, explore and understand what the tools can reveal.

In this study, research articles from the Scopus bibliometric database were used; however, as the methods applied here were based only on open source softwares, it can easily be reproduced for other bibliometric databases, broadening the perspective of the findings in the future.

Supplementary Materials: The following are available online at https://www.mdpi.com/article/10 .3390/pr9071177/s1, CSV file S1: 6417 Initial search results, as exported from Scopus, CSV file S2: 214 research articles, used in the present analysis, as exported from Scopus.

Author Contributions: Writing-original draft preparation, C.P.; review, editing G.G. All authors have read and agreed to the published version of the manuscript.

Funding: This research received no external funding.

Institutional Review Board Statement: Not applicable.

Informed Consent Statement: Not applicable.

Data Availability Statement: Not applicable.

Conflicts of Interest: The authors declare no conflict of interest. 


\section{References}

1. Gusenius, E.M. Beginnings of Greatness in Swedish Chemistry: Georg Brandt, (1694-1768). Source Trans. Kansas Acad. Sci. 1903, 70, 413-425. [CrossRef]

2. Dehaine, Q.; Tijsseling, L.T.; Glass, H.J.; Törmänen, T.; Butcher, A.R. Geometallurgy of Cobalt Ores: A Review. Miner. Eng. 2021, 160, 106656. [CrossRef]

3. Peek, E.; Akre, T.; Asselin, E. Technical and Business Consideration of Cobald Hydrometallurgy. JOM 2009, 61, 45-53. [CrossRef]

4. Hapke, M.; Hilt, G. Introduction to Cobalt Chemistry and Catalysis. Cobalt Catal. Org. Synth. 2020, 1-23. [CrossRef]

5. Kim, J.H.; Gibb, H.J. Cobalt and Inorganic Compounds; Chemical Safety Team \& International Programme on Chemical Safety; World Health Organization: Geneva, Switzerland, 2006. Available online: https://apps.who.int/iris/handle/10665/43426 (accessed on 20 April 2021).

6. Wołowiec, M.; Komorowska-kaufman, M.; Pruss, A.; Rzepa, G.; Bajda, T. Removal of heavy metals and metalloids from water using drinking water treatment residuals as adsorbents: A review. Minerals 2019, 9, 487. [CrossRef]

7. Khair, M.; Berthod, P. Thermal Properties of a Cobalt-Based Superalloy Designed to Be Reinforced by Titanium Carbides and Chromium Carbides. Mater. Phys. Chem. 2018, 1. [CrossRef]

8. Seddon, M. The Cobalt Market-Current Volatility versus Future Stability? Appl. Earth Sci. 2001, 110, 71-74. [CrossRef]

9. Mouritz, A. Introduction to Aerospace Materials, 1st ed.; Woodhead Publishing Limited: Cambridge, UK, 2012.

10. Tisserant, A.; Pauliuk, S. Matching Global Cobalt Demand under Different Scenarios for Co-Production and Mining Attractiveness. J. Econ. Struct. 2016, 5, 1-19. [CrossRef]

11. Alves Dias, P.; Blagoeva, D.; Pavel, C.; Arvanitidis, N. Cobalt: Demand-Supply Balances in the Transition to Electric Mobility; EUR 29381 EN; Publications Office of the European Union: Luxembourg, 2018; ISBN 978-92-79-94311-9. [CrossRef]

12. Gourley, S.W.D.; Or, T.; Chen, Z. Breaking Free from Cobalt Reliance in Lithium-Ion Batteries. iScience 2020, 23, 1-12. [CrossRef]

13. Shengo, M.L.; Kime, M.B.; Mambwe, M.P.; Nyembo, T.K. A Review of the Beneficiation of Copper-Cobalt-Bearing Minerals in the Democratic Republic of Congo. J. Sustain. Min. 2019, 18, 226-246. [CrossRef]

14. European Commission. Report on Critical Raw Materials and the Circular Economy; 2018. Available online: https:/ /op.europa.eu/ en/publication-detail/- / publication/d1be1b43-e18f-11e8-b690-01aa75ed71a1/language-en (accessed on 20 April 2021).

15. Bauer, D.; Diamond, D.; Li, J.; Sandalow, D.; Telleen, P.; Wanner, B. Critical Materials Strategy; 2010. Available online: https: //www.energy.gov/sites/prod/files/DOE_CMS2011_FINAL_Full.pdf (accessed on 20 April 2021).

16. Hussain, Z.; Din, M.I.; Nayab, S.; Islam, M. Recovery of Cobalt and Copper from Textile, Electroplating and Tannery Effluents Using Electrocoagulation Method. Hydrol Curr. Res 2013, 4, 147. [CrossRef]

17. Nagpal, N. Technical Report-Water Quality Guidance for Cobalt; 2004. Available online: https://www2.gov.bc.ca/assets/gov/ environment/air-land-water/water/waterquality/water-quality-guidelines/approved-wqgs/cobalt_tech.pdf (accessed on 20 April 2021).

18. Obasi, P.N.; Akudinobi, B.B. Potential Health Risk and Levels of Heavy Metals in Water Resources of Lead-Zinc Mining Communities of Abakaliki, Southeast Nigeria. Appl. Water Sci. 2020, 10. [CrossRef]

19. Palmquist, H.; Hanæus, J. Hazardous Substances in Separately Collected Grey- and Blackwater from Ordinary Swedish Households. Sci. Total Environ. 2005, 348, 151-163. [CrossRef] [PubMed]

20. Leblanc, A.; Dumas, P.; Lefebvre, L. Trace Element Content of Commercial Shampoos: Impact on Trace Element Levels in Hair. Sci. Total Environ. 1999, 229, 121-124. [CrossRef]

21. Alagappan, P.N.; Heimann, J.; Morrow, L.; Andreoli, E.; Barron, A.R. Easily Regenerated Readily Deployable Absorbent for Heavy Metal Removal from Contaminated Water. Sci. Rep. 2017, 7, 6682. [CrossRef] [PubMed]

22. Osman, D.; Cooke, A.; Young, T.R.; Deery, E.; Robinson, N.J.; Warren, M.J. The Requirement for Cobalt in Vitamin B12: A Paradigm for Protein Metalation. Biochim. Biophys. Acta-Mol. Cell Res. 2021, 1868, 118896. [CrossRef] [PubMed]

23. Evers Governor, T.; Foss, D. Recommended Public Health Groundwater Quality Standards, P-02434V; 2019. Available online: https:/ / www.dhs.wisconsin.gov/publications/p02434v.pdf (accessed on 20 April 2021).

24. Chen, L.; Huang, Y.; Huang, L.; Liu, B.; Wang, G.; Yu, S. Characterization of Co(II) Removal from Aqueous Solution Using Bentonite/Iron Oxide Magnetic Composites. J. Radioanal. Nucl. Chem. 2011, 290, 675-684. [CrossRef]

25. Mahmoud, M.E.; Saad, E.A.; El-Khatib, A.M.; Soliman, M.A.; Allam, E.A. Adsorptive Removal of Radioactive Isotopes of Cobalt and Zinc from Water and Radioactive Wastewater Using TiO2/Ag2O Nanoadsorbents. Prog. Nucl. Energy 2018, 106, 51-63. [CrossRef]

26. Tripathi, A.; Ranjan, M.R. Heavy Metal Removal from Wastewater Using Low Cost Adsorbents. J. Bioremed. Biodeg. 2015, 6. [CrossRef]

27. Mebrahtu, G.; Zerabruk, S. Concentration of Heavy Metals in Drinking Water from Urban Areas of the TigrayRegion, Northern Ethiopia. Mekelle Univ. Ethiop. 2011, 3, 105-121.

28. Thekkudan, V.N.; Vaidyanathan, V.K.; Ponnusamy, S.K.; Charles, C.; Sundar, S.L.; Vishnu, D.; Anbalagan, S.; Vaithyanathan, V.K.; Subramanian, S. Review on Nanoadsorbents: A Solution for Heavy Metal Removal from Wastewater. IET Nanobiotechnology 2017, 11, 213-224. [CrossRef] [PubMed]

29. Lison, D.; De Boeck, M.; Verougstraete, V.; Kirsch-Volders, M. Update on the Genotoxicity and Carcinogenicity of Cobalt Compounds. Occup. Environ. Med. 2001, 58, 619-625. [CrossRef] [PubMed] 
30. Musapatika, E.; Onyango, M.; Aoyi, O. Cobalt(II) Removal from Synthetic Wastewater by Adsorption on South African Coal Fly Ash. S. Afr. J. Sci. 2010, 106, 1-7. [CrossRef]

31. Tizro, S.; Baseri, H. Removal of Cobalt Ions from Contaminated Water Using Magnetite Based Nanocomposites: Effects of Various Parameters on the Removal Efficiency. J. Water Environ. Nanotechnol. 2017, 2, 174-185.

32. EU 2011/696. EC Definition of Nanomaterial; 2011; Volume 24, Available online: https:/ / eur-lex.europa.eu/LexUriServ /LexUriServ. do?uri=OJ:L:2011:275:0038:0040:EN:PDF (accessed on 20 April 2021).

33. El-sayed, M.E.A. Nanoadsorbents for Water and Wastewater Remediation. Sci. Total Environ. 2020, 739, 139903. [CrossRef] [PubMed]

34. Üzüm, Ç.; Shahwan, T.; Eroğlu, A.E.; Lieberwirth, I.; Scott, T.B.; Hallam, K.R. Application of Zero-Valent Iron Nanoparticles for the Removal of Aqueous Co2+ Ions under Various Experimental Conditions. Chem. Eng. J. 2008, 144, 213-220. [CrossRef]

35. Tahoon, M.A.; Siddeeg, S.M.; Alsaiari, N.S.; Mnif, W.; Ben Rebah, F. Effective Heavy Metals Removal Fromwater Using Nanomaterials: A Review. Processes 2020, 8, 645. [CrossRef]

36. Zhao, G.; Li, J.; Ren, X.; Chen, C.; Wang, X. Few-Layered Graphene Oxide Nanosheets as Superior Sorbents for Heavy Metal Ion Pollution Management. Environ. Sci. Technol. 2011, 45, 10454-10462. [CrossRef] [PubMed]

37. Elbedwehy, A.M.; Abou-Elanwar, A.M.; Ezzat, A.O.; Atta, A.M. Super Effective Removal of Toxic Metals Water Pollutants Using Multi Functionalized Polyacrylonitrile and Arabic Gum Grafts. Polymers 2019, 11, 1938. [CrossRef]

38. Anirudhan, T.S.; Deepa, J.R.; Christa, J. Nanocellulose/Nanobentonite Composite Anchored with Multi-Carboxyl Functional Groups as an Adsorbent for the Effective Removal of Cobalt(II) from Nuclear Industry Wastewater Samples. J. Colloid Interface Sci. 2016, 467, 307-320. [CrossRef] [PubMed]

39. Godin, B. On the Origins of Bibliometrics. Scientometrics 2006, 68, 109-133. [CrossRef]

40. Ellegaard, O.; Wallin, J.A. The Bibliometric Analysis of Scholarly Production: How Great Is the Impact? Scientometrics 2015, 105, 1809-1831. [CrossRef] [PubMed]

41. Jiang, M.; Qi, Y.; Liu, H.; Chen, Y. The Role of Nanomaterials and Nanotechnologies in Wastewater Treatment: A Bibliometric Analysis. Nanoscale Res. Lett. 2018, 13. [CrossRef]

42. Patyal, V.; Jaspal, D.; Khare, K. Wastewater Treatment Technologies: A Bibliometric Analysis. Sci. Technol. Libr. 2020, 39, 383-394. [CrossRef]

43. Li, C.; Huang, G.; Cheng, G.; Zheng, M.; Zhou, N. Nanomaterials in the Environment: Research Hotspots and Trends. Int. J. Environ. Res. Public Health 2019, 16, 5138. [CrossRef] [PubMed]

44. Zhao, L.; Deng, J.; Sun, P.; Liu, J.; Ji, Y.; Nakada, N.; Qiao, Z.; Tanaka, H.; Yang, Y. Nanomaterials for Treating Emerging Contaminants in Water by Adsorption and Photocatalysis: Systematic Review and Bibliometric Analysis. Sci. Total Environ. 2018, 627, 1253-1263. [CrossRef] [PubMed]

45. Schotten, M.; El Aisati, M.; Meester, W.J.N.; Steiginga, S.; Ross, C.A. A Brief History of Scopus: The World's Largest Abstract and Citation Database of Scientific Literature. In Research Analytics: Boosting University Productivity and Competitiveness through Scientometrics; CRC Press: Boca Raton, FL, USA, 2017; pp. 31-58.

46. Muritala, B.A.; Sánchez-Rebull, M.V.; Hernández-Lara, A.B. A Bibliometric Analysis of Online Reviews Research in Tourism and Hospitality. Sustainability 2020, 12, 9977. [CrossRef]

47. Mongeon, P.; Paul-Hus, A. The Journal Coverage of Web of Science and Scopus: A Comparative Analysis. Scientometrics 2016, 106, 213-228. [CrossRef]

48. Falagas, M.E.; Pitsouni, E.I.; Malietzis, G.A.; Pappas, G. Comparison of PubMed, Scopus, Web of Science, and Google Scholar: Strengths and Weaknesses. FASEB J. 2008, 22, 338-342. [CrossRef]

49. Waila, P.; Singh, V.K.; Singh, M.K. A Scientometric Analysis of Research in Recommender Systems. J. Scientometr. Res. 2016, 5, 71-84. [CrossRef]

50. Verma, M.K.; Shukla, R. Mapping the Research Trends on Information Literacy of Selected Countries during 2008-2017: A Scientometric Analysis. DESIDOC J. Libr. Inf. Technol. 2019, 39, 125-130. [CrossRef]

51. Mishra, M.; Sudarsan, D.; Santos, C.A.G.; Mishra, S.K.; Kar, D.; Baral, K.; Pattnaik, N. An Overview of Research on Natural Resources and Indigenous Communities: A Bibliometric Analysis Based on Scopus Database (1979-2020). Environ. Monit. Assess. 2021, 193. [CrossRef] [PubMed]

52. Clarivate Analytics. Journal Impact Factor, Journal Citation Reports. 2021. Available online: https://www.researchinformation. info/news/journal-citation-reports-2021-published-clarivate (accessed on 20 April 2021).

53. Hirsch, J.E. An Index to Quantify an Individual's Scientific Research Output. Proc. Natl. Acad. Sci. USA 2005, 102, 16569-16572. [CrossRef] [PubMed]

54. Van Eck, N.J.; Waltman, L. Software Survey: VOSviewer, a Computer Program for Bibliometric Mapping. Scientometrics 2010, 84, 523-538. [CrossRef]

55. Bastian, M.; Heymann, S.; Jacomy, M. Gephi: An Open Source Software for Exploring and Manipulating Networks Visualization and Exploration of Large Graphs. In Proceedings of the Third International ICWSM Conference (2009), San Jose, CA, USA, 19 March 2009.

56. Chai, K.E.K.; Lines, R.L.J.; Gucciardi, D.F.; Ng, L. Research Screener: A Machine Learning Tool to Semi-Automate Abstract Screening for Systematic Reviews. Syst. Rev. 2021, 10, 1-13. [CrossRef] 
57. Motulsky, H.J.; Ransnas, L.A. Fitting Curves to Data Using Nonlinear Regression: A Practical and Nonmathematical Review. FASEB J. 1987, 1, 365-374. [CrossRef] [PubMed]

58. Price, D.J. The Exponential Curve of Science. Discovery 1959, 17, 240-243.

59. Riccaboni, M.; Verginer, L. The Impact of the COVID-19 Pandemic on Scientific Research. arXiv 2021, arXiv:2102.00497.

60. Van Eck, N.J.; Waltman, L. Visualizing Bibliometric Networks. In Measuring Scholarly Impact; Springer: Berlin/Heidelberg, Germany, 2014; pp. 285-320. [CrossRef]

61. Acedo, F.J.; Barroso, C.; Casanueva, C.; Galan, J.L. Co-Authorship in Management and Organizational Studies: An Empirical and Network Analysis. J. Manag. Stud. 2006, 43, 957-983. [CrossRef]

62. Abbasi, A.; Altmann, J.; Hossain, L. Identifying the Effects of Co-Authorship Networks on the Performance of Scholars: A Correlation and Regression Analysis of Performance Measures and Social Network Analysis Measures. J. Informetr. 2011, 5, 594-607. [CrossRef]

63. Takes, F.W.; Heemskerk, E.M. Centrality in the Global Network of Corporate Control. Soc. Netw. Anal. Min. 2016, 6, 1-18. [CrossRef]

64. Kiewit, P.; Meng, Y.; Wu, D.; Li, J. Clustering Research Institutes Based on Disciplinary Layout: An Empirical Study of Chinese Academy of Sciences. Procedia Comput. Sci. 2018, 139, 537-544. [CrossRef]

65. de Andrade, R.L.; Rêgo, L.C. Exploring the Co-Authorship Network among CNPq's Productivity Fellows in the Area of Industrial Engineering. Pesqui. Operacional 2017, 37, 277-310. [CrossRef]

66. Ye, Q.; Li, T.; Law, R. A Coauthorship Network Analysis of Tourism and Hospitality Research Collaboration. J. Hosp. Tour. Res. 2013, 37, 51-76. [CrossRef]

67. Pérez-Gutiérrez, M.; Lagos-Hernández, R.; Izquierdo-Macón, E. Sport Sciences' Scientific Production Published in Chile (19122014): A Bibliometric Approach. Movimento 2016, 22, 1121-1136. [CrossRef]

68. Jacomy, M.; Venturini, T.; Heymann, S.; Bastian, M. ForceAtlas2, a Continuous Graph Layout Algorithm for Handy Network Visualization Designed for the Gephi Software. PLoS ONE 2014, 9. [CrossRef]

69. El-Shafey, E.I.; Cox, M.; Pichugin, A.A.; Appleton, Q. Application of a Carbon Sorbent for the Removal of Cadmium and Other Heavy Metal Ions from Aqueous Solution. J. Chem. Technol. Biotechnol. 2002, 77, 429-436. [CrossRef]

70. Üzüm, Ç.; Shahwan, T.; Eroğlu, A.E.; Hallam, K.R.; Scott, T.B.; Lieberwirth, I. Synthesis and Characterization of KaoliniteSupported Zero-Valent Iron Nanoparticles and Their Application for the Removal of Aqueous Cu 2+ and Co 2+ Ions. Appl. Clay Sci. 2008, 43, 172-181. [CrossRef]

71. Tuutijärvi, T.; Lu, J.; Sillanpää, M.; Chen, G. As(V) Adsorption on Maghemite Nanoparticles. J. Hazard. Mater. 2009, 166, 1415-1420. [CrossRef] [PubMed]

72. Fang, F.; Kong, L.; Huang, J.; Wu, S.; Zhang, K.; Wang, X.; Sun, B.; Jin, Z.; Wang, J.; Huang, X.-J.; et al. Removal of Cobalt Ions from Aqueous Solution by an Amination Graphene Oxide Nanocomposite. J. Hazard. Mater. 2014, 270, 1-10. [CrossRef]

73. Tayebikhorami, S.; Nikoo, M.R.; Izady, A.; Adamowski, J. A Novel CVaR-Based Conflict Resolution Model for Optimal Allocation of Treated Wastewater under Bankruptcy Conditions. J. Clean. Prod. 2020, 252. [CrossRef]

74. Mureseanu, M.; Reiss, A.; Stefanescu, I.; David, E.; Parvulescu, V.; Renard, G.; Hulea, V. Modified SBA-15 Mesoporous Silica for Heavy Metal Ions Remediation. Chemosphere 2008, 73, 1499-1504. [CrossRef] [PubMed]

75. Shahat, A.; Rabiul Awual, M.; Naushad, M. Functional Ligand Anchored Nanomaterial Based Facial Adsorbent for Cobalt(II) Detection and Removal from Water Samples. Chem. Eng. J. 2015, 271, 155-163. [CrossRef]

76. Afkhami, A.; Saber-Tehrani, M.; Bagheri, H. Simultaneous Removal of Heavy-Metal Ions in Wastewater Samples Using NanoAlumina Modified with 2,4-Dinitrophenylhydrazine. J. Hazard. Mater. 2010, 181, 836-844. [CrossRef] [PubMed]

77. Hokkanen, S.; Repo, E.; Sillanpää, M. Removal of Heavy Metals from Aqueous Solutions by Succinic Anhydride Modified Mercerized Nanocellulose. Chem. Eng. J. 2013, 223, 40-47. [CrossRef]

78. Tofighy, M.A.; Mohammadi, T. Adsorption of Divalent Heavy Metal Ions from Water Using Carbon Nanotube Sheets. J. Hazard. Mater. 2011, 185, 140-147. [CrossRef] [PubMed]

79. Liu, M.; Chen, C.; Hu, J.; Wu, X.; Wang, X. Synthesis of Magnetite/Graphene Oxide Composite and Application for Cobalt(II) Removal. J. Phys. Chem. C 2011, 115, 25234-25240. [CrossRef]

80. Chang, Y.-C.; Chang, S.-W.; Chen, D.-H. Magnetic Chitosan Nanoparticles: Studies on Chitosan Binding and Adsorption of Co(II) Ions. React. Funct. Polym. 2005, 66, 335-341. [CrossRef] 